UNIVERSITY OF GOTHENBURG

SCHOOL OF BUSINESS, ECONOMICS AND LAW

WORKING PAPERS IN ECONOMICS

No 417

Ethnic Cleansing or Resource Struggle in Darfur?

An empirical analysis

Ola Olsson

Eyerusalem Siba

November 2009

ISSN 1403-2473 (print)

ISSN 1403-2465 (online) 


\title{
Ethnic Cleansing or Resource Struggle in Darfur? An Empirical Analysis
}

\author{
Ola Olsson* \\ University of Gothenburg
}

\author{
Eyerusalem Siba \\ University of Gothenburg
}

November 24, 2009

\begin{abstract}
The conflict in Darfur has been described both as an ethnic cleansing campaign, carried out by the Sudanese government and its allied militias, and as a local struggle over dwindling natural resources between African farmers and Arab herders. In this paper, we construct a theoretical framework for understanding the choice between ethnic cleansing and resource capture and use a previously unexploited data set on 530 villages in Southwestern Darfur to analyze the determinants of attacks in the region. Our results clearly indicate that Janjaweed attacks have been targeted at villages dominated by the major rebel tribes, resulting in a massive displacement of those populations. Resource variables, capturing access to water and land quality, also have some explanatory power but are not consistently significant. These patterns suggest that attacks in the area had ethnic cleansing as a primary objective.
\end{abstract}

Key words: Ethnic cleansing, resource struggle, Darfur

JEL Classification codes: P16, O41

${ }^{*}$ The findings, interpretations, and conclusions expressed in this paper are entirely those of the authors. Although data has been generously shared by some international organizations, our research has been fully independent at all stages. We are grateful for very helpful comments from Michael Bleaney, Erwin Bulte, Olof Johansson-Stenman, Michael Kevane, Ted Miguel, Oliver Morrissey, Katarina Nordblom, Måns Söderbom, Marie-Anne Valfort, Daniel Zerfu, Joakim Westerlund, and from seminar participants at UC Berkeley, University of Gothenburg, University of Nottingham, and University of Paris 1 - Sorbonne. Michele Valsecchi provided excellent research assistance. Email: ola.olsson@economics.gu.se. 


\section{Introduction}

The conflict in Darfur is one of the worst humanitarian disasters in the world. Since the onset of hostilities in 2003, it is estimated that some 300,000 people have died and that 2.7 million people have fled their homes (BBC, 2008). In a statement before the US Congress, State Secretary Colin Powell referred to the conflict as a genocide already in September, 2004. ${ }^{1}$ The war has led to a massive international aid operation as well as the deployment of a large UN-backed peace-keeping force. On March 4, 2009, the prosecutor of the International Criminal Court in the Hague issued a warrant of arrest for Sudan's incumbent president Omar al-Bashir for war crimes and crimes against humanity in Darfur (ICC, 2009).

In this article, we analyze the determinants of attacks on villages in Darfur. We first provide a conflict theory framework for understanding the choice between ethnic cleansing and resource capture. We then introduce our previously unexploited data set on 530 villages in Southwestern Darfur, hosting a total of about 144,000 households, collected by an international organization working in the area. Unlike other samples from Darfur, our data has detailed information about the ethnic composition before and after the war began and comprises all known rural villages in the area. Our findings strongly indicate that attacks have been primarily motivated by an ethnic cleansing campaign aimed at three traditionally dominant African groups who announced their opposition to the government in 2003. Arab-dominated villages, on the other hand, are very rarely attacked.

Using satellite imagery, we further create a proxy variable for each village's access to surface water (distance to a major wadi, i.e. a seasonally dry river) and exploit data from FAO (1998) on rainfall, vegetational cover, temperature, and soil quality. The results from our regression analysis suggest that more resourceful villages appear to have a higher risk and intensity of attacks, but the marginal effects of natural resource access are smaller and the estimates are not always significant. Our study further documents a dramatic demographic reversal as a result of the cleansing campaign with Arabs and new African tribes replacing fleeing rebel tribes.

Although the roots of the conflict in Darfur are complex, two main dimensions have been proposed in the literature: a) A long-standing and primarily local conflict about land between farmers and pastoralists, aggravated by a worsening climate. b) A core-periphery conflict between an Arab government and a small number of oppositional African ethnic groups that have traditionally held a dominant position in Darfur. ${ }^{2}$

The first conflict dimension, suggesting a local struggle over dwindling natural re-

\footnotetext{
${ }^{1}$ In Powell's own words: "When we reviewed the evidence compiled by our team, along with other information available to the State Department, we concluded that genocide has been committed in Darfur and that the Government of Sudan and the jinjaweid bear responsibility - and genocide may still be occurring." (America.Gov, 2004). It is further interesting to note that the investigation commissioned by the UN Security Council found evidence of crimes against humanity but not of genocide (United Nations, 2005)

${ }^{2}$ See Brosché (2008) for an overview of the relevant conflict dimensions. Brosché actually adds a third important conflict dimension in Darfur; a proxy war between the governments of Chad and Sudan.
} 
sources, is similar to the official view held by the government in Khartoum. The government consistently denies any links to the Arab militias that have been accused of carrying out most of the violence. Government representatives even claim that the death toll is much lower than reported by the UN, probably no more than 10,000 people (Prunier, 2007). The importance of land degradation and a deteriorating climate has also been emphasized by UNEP (2007) and by UN Secretary General Ban Ki-Moon (2007). Among economists, Sachs (2006) has argued that climate change is the root cause of the current disaster and supports his line of argumentation on the finding that decreased rainfall have been shown to have an indirect effect on conflict risk in Africa via economic growth (Miguel et al, 2004).

This view has been criticized by Kevane and Gray (2008). Their analysis of annual precipitation in Darfur from the early 1970s onwards do not seem to suggest a decline in rainfall around 2003 when the conflict started. Hence, Kevane and Gray argue that the direct link between diminishing resources and conflict is not supported by the data and that the main reason for current hostilities is the government's exceptional willingness to crush political opposition. A related argument is made by Prunier (2007) who suggests that the scale of the conflict reflects a counter-insurgency that was initially organized by the government but which eventually went out of hand. This is also the standpoint of the International Criminal Court who, in its warrant of arrest for al-Bashir, accuses the Sudanese government for being responsible for initiating and conducting (together with allied forces) a counter-insurgency involving serious crimes against humanity, mainly aimed at the three rebel tribes Fur, Masalit, and Zaghawa (ICC, 2009).

A central proposition that is investigated in this article is that the government and its allied militias potentially have been motivated by an ambition to carry out ethnic cleansing in large parts of Darfur. We adhere to the definition of ethnic cleansing provided by Petrovic (1994, p 351), claiming that "...ethnic cleansing is a well-defined policy of a particular group of persons to systematically eliminate another group from a given territory on the basis of religious, ethnic or national origin." As such, ethnic cleansing typically involves violence on a large scale and a series of specific crimes against humanity such as murder, mass rape, torture, and forced displacement of populations (Bell-Fialkoff, 1993; Petrovic, 1994). ${ }^{3}$ The phenomenon has not been extensively covered in the social science literature, the main exception being Mann (2005).

In general, Darfur has also attracted surprisingly little attention in the economics literature. Apart from Kevane and Gray (2008), Olsson (2009) develops a theoretical framework for understanding how resource scarcities might give rise to "neo-Malthusian" social conflicts and then applies the model in an informal fashion on the Darfuri context. Van den Brink et al (1995) deal with the farmer-pastoralist conflicts in the Sahel region to which Darfur belongs. ${ }^{4}$

In the wider social science literature, Hagan and Rymond-Richmond (2008) study the

\footnotetext{
${ }^{3}$ See section 2.2 for a further discussion about ethnic cleansing.

${ }^{4}$ See also the overview article by Turner (2004).
} 
mechanisms behind the Darfuri conflict from a sociological angle and identify the Sudanese government's racist "Arabization" ideology as key for understanding the acceptance among local Arabs to participate in the ethnic cleansing campaigns. In their empirical analysis of 932 interviews collected by the American Bar Foundation, Hagan and Rymond-Richmond (2008) find that only three African groups were targeted by the attacks and that the most detrimental attacks were carried out by the government in cooperation with the local Arab militias. Vanrooyen et al (2008) carried out interviews among refugees in Chad in order to analyze in detail the nature of the attacks and the scope of human and resource losses in three villages. ${ }^{5}$

The empirical study in this paper is related to a large volume of articles studying the general determinants of civil war and social conflict using cross-country data (Collier and Hoeffler, 1998, 2004; Fearon and Laitin, 2003; Miguel et al, 2004). ${ }^{6}$ The specific role of environmental stress and scarcities is given particular attention in Homer-Dixon (1994), Diamond (2005), and Schubert et al (2008), but more formal statistical analyses have generally not found any strong effect of environmental stress on conflict risk (Nordås and Gleditsch, 2007).

The analysis in this paper is one of few other attempts at analyzing the determinants of violence on micro level. Buhaug and Röd (2006) study the determinants of civil war in Africa by using grid cells with a resolution of $100 \times 100 \mathrm{~km}$ as the basic unit of analysis. Among other things, they show that the probability of conflict onset increases with distance from the country capital and with the presence of conflict in neighbouring regions. In a study of more than 5,000 villages in Aceh, Indonesia, Czaika and Kis-Katos (2007) find that ethnicity does not seem to matter much for (forced) migration patterns and that general socio-economic variables matter more. Other studies with conflict intensity as the dependent variable include Murshed and Gates (2005) and Do and Iyer (2007) (on 75 districts in Nepal) and Bellows and Miguel (2006) (on 152 chiefdoms in Sierra Leone). ${ }^{7}$ What makes our study unique compared to the studies above is primarily the detailed data on village level of the ethnic composition before and after the onset of the conflict. Also, unlike any of the papers above, we find robust evidence of aggression primarily targeted at certain ethnic groups.

In summary, we believe our study makes the following contributions to the literature: Firstly, we provide the first large-sample empirical analysis of the determinants of attacks on villages in Darfur. Secondly, unlike most other studies in the conflict literature, we use a survey that has aimed to include the whole population in an area of more than 500 villages with very detailed information on demographic composition before and after con-

\footnotetext{
${ }^{5}$ Further studies include Depoortere et al (2004), who provide estimates of mortality during the first year of the crisis. Bloodhound, a Denmark-based NGO, has independently compiled a large number of witness accounts of attacks in Darfur (Petersen and Tullin (2006a). The only somewhat optimistic study on Darfur is Schimmer (2008) which shows that the large population and livestock displacements have recently resulted in a resurge of vegetation in the area.

${ }^{6}$ See Blattman and Miguel (2008) for a recent survey of the literature on the determinants of civil war.

${ }^{7}$ See also André and Platteau (1998) and Verwimp (2005) who both study individual-level data from Rwanda and show that land stress appears to have played a key role for the conflict outbreak in 1994.
} 
flict. Thirdly, our paper demonstrates beyond reasonable doubt that a major explanation of violence in Southwestern Darfur is a government-led campaign of ethnic cleansing targeted at the major African tribes Fur and Masalit, whereas the resource-based hypothesis receives some but less clear support.

Our article is structured as follows: In section 2, we provide a general background to the conflict in Darfur and discuss the nature of ethnic cleansing. In section 3, we outline a conflict theoretical framework in order to clarify the key causal linkages. The data, the empirical strategy, and the regression analysis are presented in section 4, whereas section 5 concludes.

\section{Background $^{8}$}

\subsection{The Darfur conflict}

Darfur is Sudan's westernmost province, sharing an extensive border with Chad in the west and with an area of roughly 500,000 sq $\mathrm{km}$ (approximately the size of Spain). Its northern parts are largely uninhabited desert areas, whereas the central and southern parts belong to the African Sahel belt. The most fertile lands are found on the slopes of the Jebel Marra mountains which traditionally have been regarded as the core of the region. Rainfall is more abundant on the Jebel Marra than in the surrounding semi-arid plains and the highland plateau has therefore served as a kind of refuge during years of drought.

Darfur is believed to host about 6.5 million inhabitants belonging to a multitude of ethnic groups. The population is often subdivided into "African" and "Arab" tribes, although the distinction between the two is not always clear. The African tribes are usually sedentary agriculturists and include some of the largest and traditionally most influential groups such as the Fur tribe, which has given the region its name. ${ }^{9}$ The Arab tribes are typically either cattle or camel herders and practice a nomadic lifestyle with seasonal migrations across farmer lands. Both the African and Arab tribes are Muslim and Arabic serves as a lingua franca in the region.

The recent conflict in Darfur is generally regarded to have started in February 2003 when the JEM and the SLA rebel groups announced their programs in opposition to the government in Khartoum. The SLA group consisted mainly of Fur and Masalit tribesmen, whereas JEM was dominated by the African (yet nomadic) Zaghawa tribe. Both groups claimed that the basic reason for their rebellion was the consistent marginalization of Darfur in a national context. After some successful initial attacks on government outposts, which appeared to catch the Sudanese government by surprise, a counter-insurgency was launched during the second half of 2003. Since the Sudanese army was still engaged in the south of the country to secure the emerging peace process with the SPLA rebels, the

\footnotetext{
${ }^{8}$ The general information in this section builds mainly upon Prunier (2007) and Flint and de Waal (2008).

9 "Darfur" means literally "the land of the Fur".
} 
government chose to mobilize loyal Arab tribes in Darfur to fight SLA and JEM (Prunier, 2007; Flint and de Waal, 2008; ICC, 2009).

The war now entered its most intense stage. Supported by government intelligence and aircraft, the Arab militias - referred to locally as the Janjaweed - attacked hundreds of African villages throughout Darfur during late 2003 and early 2004. The typical pattern was an initial bombing by Antonov airplanes or helicopter gunships, whereupon the Janjaweed would move in, mounted on camels or small pickup trucks, and kill many civilians, rape women and girls, shoot or steal livestock, destroy as much equipment as possible, poison the wells, and eventually set the whole village ablaze (Petersen and Thulin, 2006a, 2006b; Prunier, 2007; Hagan and Rymond-Richmond, 2008; Vanrooyen et al, 2008). Many villages were totally abandoned after such attacks and the surviving population fled to refugee camps near the larger towns or just west of the Chadian border. Similar attacks have repeatedly occurred also after the most intense campaigns in winter 2004. By winter 2008, it was estimated that the crisis has resulted in some 300,000 deaths and about 2.7 million refugees (BBC, 2008).

It has been argued that the conflict in Darfur has at least two key dimensions. ${ }^{10}$ The most obvious dimension is the tension between an Arab center of the country in Khartoum and a marginalized African population in the periphery. Darfur was not included into the British colony until 1916 and had previously been an autonomous sultanate for hundreds of years with an own sense of identity. The colonial government, as well as the governments of independent Sudan, have had in common a total lack of interest in developing Darfur. Even within government circles in Khartoum, suggestions were circulated in 2001 of a broader social inclusion of all regions in Sudan, but president Omar al-Bashir reacted strongly against such ideas.

The current conflict in Darfur also has deep roots within the social fabric of Darfur itself. It represents a rapid escalation of a conflict that has long divided different groups in Darfur over land use and competition for scarce natural resources, particularly water. According to the customary land tenure system in Darfur each small tribe is allocated a hakura, a piece of land that they can use in usufruct. Any land left un-used for a significant amount of time will be returned back to communal use and will be subject to redistribution. The land in Darfur has been customarily owned by the biggest ethnic groups indigenous to the area - the Fur and the Masalit. The communal leaders of these tribes, the sultans, omdas and sheiks, were responsible for the administration of the dar. It was they who gave permission to the outsiders to reside in villages and who allocated land to the newcomers and to the minority groups. Newcomers have to approach tribal leaders of indigenous land holding tribes in order to permanently settle and be allocated land provided that they adhere to the customary regulations and authority of the host tribes. Grazing, hunting and forest use rights are also obtained similarly. The best and fertile land,however, was allocated to the original inhabitants, as did administrative authority and

\footnotetext{
${ }^{10}$ See Brosché (2008) and Prunier (2007) for an in-depth analysis of the multicausal nature of the Darfuri conflict.
} 
functions (Abdul-Jalil, 2006). ${ }^{11}$

As a result, there is a clear social stratification among Darfurians in relation to access to land into two: dar owners - the indigenous people and cattle nomads and non-dar owners, including Arabic camel nomads and new-comers who migrated from Chad and northern Darfur due to drought of the 1970s and 80s. The new African arrivals among the late-comers in 70 s and 80 s were farmers and could freely settle in the region. ${ }^{12}$ The local administration, however, was still solidly in the hands of the native inhabitants, in accordance with the traditional dar system. Essentially, the new African arrivals were well integrated with the dar owners, but occupied a lower social and economic status. ${ }^{13}$

The traditional system of managing resources facilitated relatively peaceful coexistence between nomads and farmers. The Arab Nomads (particularly the camel nomads) had no dar of their own. Instead, they made seasonal movements, south and north, in search of water and pasture for their herds. In the past, this has been done without friction as land was abundant and nomadic groups had no problem with such arrangement as it allows them to take advantage of a variety of ecological regions. During the farming season, nomadic movements were restricted to certain annually-marked traditional routes, called migration routes. After the harvesting season, the nomads were allowed to use all of the grazing land, except for the fenced vegetable/fruit gardens. Conflicts and disputes among tribes and individuals were settled by the traditional authorities (O'Fahey \& Tubiana, 2009; Abdul-Jalil, 2006).

The colonial government (1917-1956) recognized the dar system. When Darfur was finally annexed to Sudan in 1916 the colonial authorities introduced little changes to the then existing system of administration. Under their policy of indirect rule they confirmed tribal leaders as part of a native administration system and custodians of land belonging to their tribes. However, the dar-system was formally abolished by the central GoS in 1970, without being replaced with mechanisms that would eventually facilitate the relationship between nomads and farmers. The consequence was the disappearance of the various "Native Courts". With them disappeared much expertise on such issues as land tenure and the resolution of inter-ethnic conflicts. However, the abolition was never complete though the old system was severely weakened. It remained as a parallel authority structure embedded in the state making a number of land tenure systems co-exist in Darfur (O'Fahey \& Tubiana, 2009; Abdul-Jalil, 2006).

\footnotetext{
${ }^{11}$ O'Fahey \& Tubiana (2009) document that the Darfur sultanate had its roots in the Fur people; the great offices of state were always held by Fur, even when the sultans recruited non-Fur to serve them, which has left a legacy relevant to the present, especially to the Fur people. According to the authors, continuous conflict and tension between the old-established power-holders, largely Fur, and the 'new men', Arab and non-Arab is still current in Darfur since the 19th century.

${ }^{12}$ Such as the Tama, Gimier, Mararit, Eringa, Kajaksa, Borgo, Mesiria Jabal, Mimi, Singar, Dajo and Falatta tribes.

${ }^{13}$ Anecdotal evidence also indicates that when the conflict erupted in August 2003, many of the 'new' African tribes chose not to side with the traditional African tribes of the area which made them considered by the other African groups as 'collaborators'. Their position was presumably influenced by the prospect of gaining better land through collaboration as well as by the fact that their limited numbers put them at risk of losing their animals in the conflict.
} 
The issue of land became more critical following the growing pressures on natural resources as a result of land degradation and desertification, combined with expanding rain fed and wadi cultivation to meet the demands of increased population. Expansion of agricultural land triggers blocking of animal migration routes and decreased access to water sources for animals which has been one of the common causes of grassroots conflicts in Darfur (Abdul-Jalil, 2006).

\subsection{Ethnic cleansing}

As discussed in the introduction, ethnic cleansing is most often described as a sustained attempt by one group to remove another group - defined in ethnic, religious, or political terms - from a given territory. In this sense, ethnic cleansing can be distinguished from the related term "genocide" by the notion that whereas the former features an intent to remove a population, the latter aims at destroying a population, in whole or in part (Petrovic, 1994). It might thus be argued that genocide is necessarily always also an act of ethnic cleansing, but the reverse needs not to be true. ${ }^{14}$

A further difference is that while genocide is described by a specific UN convention from 1948, ethnic cleansing is not defined by international law. ${ }^{15}$ Rather, ethnic cleansing can be understood as an overarching term for a series of crimes against humanity such as massive deportation, torture, murder, large scale rape and sexual assaults, for war crimes such as attacking civilian targets with military, as well as for other crimes such as robbery, destruction of homes and livelihoods, destruction of cultural and religious monuments, verbal harassments, and the use racist propaganda, all with the aim of removing a particular group from a territory (Petrovic, 1994).

Though the term ethnic cleansing did not become commonly used until the early 1990s during the conflict in former Yugoslavia, the phenomenon is far from new. Bell-Fialkoff (1993) traces incidents of ethnic cleansing at least back to an Assyrian ruler in the 700s $\mathrm{BC}$ who was known to have made forced resettlement a state policy. During the Middle Ages, various religious groups were often violently expelled from countries, for instance Jews (from Spain, England, France, and other countries), and Protestant Huguenots were famously expelled from France in the late 1680s. The Armenian holocaust in 1915, when an estimated 1.5 million Armenians succumbed in the Ottoman empire, and the Holocaust during World War II, both involved massive ethnic cleansing campaigns alongside outright exterminations. The most well-known example of ethnic cleansing during recent years is undoubtedly the war in Bosnia-Herzegovina in the early 1990s.

In 2004, a Security Council resolution requested that an investigation should be carried out on the situation in Darfur concerning alleged violations of international law. The

\footnotetext{
${ }^{14}$ Mann (2005) uses the term "murderous ethnic cleansing" to describe all kinds of activities involving extreme violence on a massive scale aimed at a certain population. According to this definition, genocide is therefore the most extreme form of murderous ethnic cleansing.

${ }^{15}$ It is, however, mentioned in a Security Council Resolution from 2006, stating that member countries should assume the responsibility "...to protect populations from genocide, war crimes, ethnic cleansing and crimes against humanity." (Security Council, 2006, p 2)
} 
investigation was also commissioned to determine whether acts of genocide had occurred. Their conclusion, reported in 2005, was that

"...the Commission found that the Government of Sudan and the Janjaweed are responsible for serious violations of international human rights and humanitarian law...the Commission found that Government forces and militias conducted indiscriminate attacks, including killing of civilians, torture, enforced disappearances destruction of villages, rape and other forms of sexual violence, pillaging and forced displacement, throughout Darfur. These acts were conducted on a widespread and systematic basis, and therefore may amount to crimes against humanity." (United Nations, 2005, p 3)

However, the report also concluded that the aggression should not be referred to as a genocide since the investigators could not find evidence of a policy aimed at exterminating a specific subpopulation:

"Rather, it would seem that those who planned and organized attacks on villages pursued the intent to drive the victims from their homes, primarily for purposes of counter-insurgency warfare." (United Nations, 2005, p 4).

On the basis of this literature overview, we hypothesize in the sections ahead that ethnic cleansing ambitions could have been a key determinant of attacks on villages in Darfur.

\section{$3 \quad$ A Model}

\subsection{Basic assumptions}

In order to clarify the setting for the empirical analysis, let us imagine a very simple model with two types of collective agents; a roaming group of $N>0$ potential predators on the one side, and a number of villages $(i=1,2, \ldots)$ whose populations $L_{i}>0$ will potentially be preyed upon, on the other. The key decision in the model is the predators' choice whether to attack some village $i$ or not. What we mainly aim to illustrate is that this decision will crucially depend on the predators' preference structure, i.e. whether their objective is to capture resources or whether they aim to cleanse the village from a particular subpopulation. ${ }^{16}$

We assume that predators gain utility from two sources: From consumption of their own (peaceful) normal production $Q$ and from a prize attained by fighting, $P$. Total utility is $U(Q, P)$ where marginal utilities are $U_{Q}>0$ and $U_{P}>0$. Total available predator effort

\footnotetext{
${ }^{16}$ As discussed further below, we consider the Janjaweed and the government forces to be making up a single collective agent in this model. Admittedly, it could be the case that their motivations were somewhat different so that the parameter describing the relative preference for ethnic cleansing should be seen as a compromise that the two had agreed upon.
} 
is normalized to unity. Effort devoted to fighting is $f \in[0,1]$ and the effort aimed at peaceful production is $1-f$.

Peaceful normal production is given by $Q=A(1-f)$ where $A>0$ is a labor productivity parameter capturing things like the quantity and quality of physical factors of production, as well as climate and institutional quality. Production is the normal activity even for potential predators.

The prize that can be attained through fighting has two components: Resource capture and ethnic cleansing. In case of a predator attack, the resources lost to village $i$ are $\rho r_{i} L_{i}$ where $\rho \in[0,1]$ is the share of all available resources in $i$ that the attackers conquer or destroy, specified further below. The total size of appropriable resources in village $i$ is $r_{i} L_{i}$ where $r_{i}>0$ is resources per capita and where $L_{i}$ is the total size of the population. For simplicity, we assume that the size of the total resource stock increases proportionally with population.

Utility from ethnic cleansing equals the number of people from a specific targeted population group $j$ with a size $L_{i}^{j} \in\left[0, L_{i}\right]$ that the predators manage to remove from village $i .^{17}$ The total size of ethnic cleansing in village $i$ is $\rho L_{i}^{j}=\rho a_{i} L_{i}$ where $\rho$ is the proportional success of the predators, as above, and where $a_{i}$ is the fraction of village $i$ :s total population that belongs to the targeted group.

However, an important assumption is further that the predators' ability to discriminate among groups in the village is imperfect. As a result of the attack, a fraction $\rho$ of the rest of the population is also forced to flee so that the total number of displaced people is simply $\rho L_{i} \cdot{ }^{18}$

The total prize of predatory activities takes the Cobb-Douglas form

$$
P=\left(\rho r_{i} L_{i}\right)^{\alpha}\left(\rho L_{i}^{j}\right)^{1-\alpha}=\rho L_{i} r_{i}^{\alpha} a_{i}^{1-\alpha}
$$

where the parameter $\alpha \in[0,1]$ describes the relative utility gained from resource capture. Obviously, if $\alpha>1 / 2$, the attacker is mainly driven by a desire to capture or destroy resources, whereas an $\alpha<1 / 2$ would indicate an attacker primarily motivated by the prospect of ethnic cleansing. An assumption of $\alpha=1$ would transform the model into one of pure resource conflict, which is the standard setup in the literature. Note also that marginal utility of resource capture increases with the level of ethnic cleansing, and vice versa.

We assume that the proportional success of predatory aggression $\rho$ is given by a non-

\footnotetext{
${ }^{17}$ The motivation for the attackers' desire to displace group $j$ will be taken as exogenously given in this model.

${ }^{18}$ Since a proportion $\rho$ of both resources and population are destroyed/displaced in the attack, resources per capita remains constant. The ratio $L_{i}^{j} / L_{i}=a_{i}$ further remains constant in the individual village. But if villages with a high $a_{i}$ are consistently targeted, there will be a disproportionate displacement of people from group $j$ is the population in the area as a whole.
} 
linear contest success function

$$
\rho\left(f_{i}\right)=\left\{\begin{array}{c}
\frac{\theta f_{i} N}{\theta f_{i} N+L_{i}} \text { iff } \frac{\theta f_{i} N}{\theta f_{i} N+L_{i}}<d \\
1 \text { otherwise }
\end{array}\right.
$$

where $\theta$ reflects the relative military strength of the predators, $f_{i} N$ is total predator effort devoted to attacking village $i$, i.e. each attacker's effort $f_{i}$ times total number of predators $N$, and $d<1$ is some critical level beyond which the whole population abandon the village. $\theta>1$ means that the predators are more effective on the margin than the defenders, and vice versa with $\theta<1 .{ }^{19}$ It is straightforward to show that $\rho$ is positive and concave in $f_{i} N$ and negative and convex in $L_{i}$. Furthermore, $\rho$ is an increasing, concave function of $\theta$. The whole village population $L_{i}$ take part in the defense (if they remain in the village).

Compared to existing models, we make the original assumption that beyond a certain level $d$, the entire population $L_{i}$ abandon their homes. At this level - where both a large fraction of the population are removed and where an equally large fraction of all resources are stolen or destroyed - staying behind is no longer feasible for the remaining households. We would argue that this assumption is realistic in the case of small rural villages, which is the object of our empirical study. When $L_{i}$ then switches to zero, $\rho\left(f_{i}\right)$ switches to unity.

The function in (2) can further be rewritten so as to implicitly define a critical level if fighting effort $\tilde{f}$ given by $\rho\left(\tilde{f}_{i}\right)=d$. Beyond this level of predator effort, all resources are captured or destroyed and the village is abandoned. Some algebra shows that this level is

$$
\tilde{f}_{i}=\frac{L_{i} d}{\theta N(1-d)} .
$$

Note that we make the key assumption that the success of resource conquest and of ethnic cleansing can be described by the same function (2). What this implies is that the two types fighting always are complementary: A predator motivated by conquering for instance land resources will typically also need to drive away the originial owners from their homes in order to secure his conquest, and a predator motivated by ethnic cleansing will usually steal or destroy as much resources in the village as possible so that its original inhabitants cannot return. ${ }^{20}$

At each moment in time, the predators can choose between attacking one village $i$ or pursuing normal production. Let us further assume a utility function where $P$ and $Q$ are separable and perfect substitutes:

$$
\begin{aligned}
U\left(Q_{i}, P_{i}\right) & =P_{i}+Q_{i}= \\
& =\rho\left(f_{i}\right) \cdot L_{i} r_{i}^{\alpha} a_{i}^{1-\alpha}+\left(1-f_{i}\right) A
\end{aligned}
$$

\footnotetext{
${ }^{19}$ See Grossman and Kim (1995) and Olsson and Congdon Fors (2004) for a similar assumption.

${ }^{20}$ Alternatively, one might regard resource looting as an externality from attempts at ethnic cleansing, and vice versa. Mann (2005) provides a number of historical examples supporting this assumption. For instance, he demonstrates how the ethnic cleansing of Indians in North America was typically followed by a take-over of Indian lands.
} 
As will be shown, the two key components of what will determine the fate of village $i$ are resources per capita $r_{i}$, the proportional size of the targeted population $a_{i}$, and the predators' underlying relative preference for ethnic cleansing $1-\alpha$.

\section{$3.2 \quad$ Optimal predatory effort}

From the point of view of the attacker, the utility function in (4), together with the contest success function in (2), constitute an optimal effort allocation problem. How much effort should be devoted to attacking village $i$ ?

The first derivative is

$$
\frac{\partial U}{\partial f_{i}}=\frac{\theta N L_{i}^{2} r_{i}^{\alpha} a_{i}^{1-\alpha}}{\left(\theta N f_{i}+L_{i}\right)^{2}}-A .
$$

The most basic insight is that the marginal utility of fighting efforts increases with the level of resources $r_{i}$ and with the share of the targeted population $a_{i}$. The strength of these marginal effects depend on the preference parameter $\alpha$.

The normal situation in most societies is that (5) is negative at all $f_{i} \leq 1$, implying that the marginal utility of effort in peaceful production exceeds the marginal utility of fighting at all possible levels of fighting. In that case, optimal predatory effort is of course $f_{i}^{*}=0$ and the level of indirect utility is $V(0)=A$. Such a scenario is depicted as case I in figure 1.

If there exists some $f_{i}$ in the range $\left(0, \tilde{f}_{i}\right)$ where (5) is positive, then $f_{i}^{*}>0$ and there will be an attack. Should there be a maximum in the permissible range, then it is given by the level of $f_{i}$ where (5) equals zero:

$$
\begin{aligned}
f_{i}^{\max } & =\frac{L_{i}}{\theta N}\left(\sqrt{\frac{\theta N r_{i}^{\alpha} a_{i}^{1-\alpha}}{A}}-1\right) \in\left(0, \tilde{f}_{i}\right) \\
\operatorname{iff} r_{i}^{\alpha} a_{i}^{1-\alpha} & >\frac{A}{\theta N} \text { and }\left.\frac{\partial U}{\partial f_{i}}\right|_{f_{i}=\tilde{f}_{i}}<0
\end{aligned}
$$

The necessary condition for $f_{i}^{\max }$ to exist is that the term under the square root sign is larger than unity, i.e. that $r_{i}^{\alpha} a_{i}^{1-\alpha}>\frac{A}{\theta N}$. To start with, it is noteworthy that the probability of any type of attack will increase with $\theta N$ and decrease with $A$. This is certainly in line with intuition: All else equal, predatory aggression should be more likely the greater the number $N$ and relative military strength $\theta$ of the attackers and the lower the marginal product of peaceful activities $A .^{21}$ It is further only natural that an attack is more likely if there are plenty of resources per inhabitant $r_{i}$ and if the ratio of the targeted population to the whole population $a_{i}$ is high.

However, even if such an interior maximum exists, this might not be the optimal fighting effort since indirect utility might still be higher at the critical level of effort where $f_{i}=\tilde{f}_{i}$. This is also shown in case II of figure 1 where the indirect utility $V\left(\tilde{f}_{i}\right)$ exceeds

\footnotetext{
${ }^{21}$ Similar results have been derived in many other conflict models, for instance Olsson and Congdon Fors (2004).
} 
the indirect utility of $f$ at is maximum, $V\left(f_{i}^{\max }\right)$. Comparing the two levels by inserting (3) and (6) into (4), gives the following result:

$$
\begin{aligned}
V\left(\tilde{f}_{i}\right)-V\left(f_{i}^{\max }\right)= & \frac{A L_{i}}{\theta N}\left(2 \sqrt{\frac{\theta N r_{i}^{\alpha} a_{i}^{1-\alpha}}{A}}-\frac{1}{(1-d)}\right)= \\
& A\left(2 f_{i}^{\max }-\frac{L_{i}(2 d-1)}{\theta N(1-d)}\right)=y^{*}\left(r_{i}, a_{i}\right) .
\end{aligned}
$$

A village will thus be destroyed if the function $y^{*}\left(r_{i}, a_{i}\right)>0$ where the partial derivatives are $y_{r}^{*}\left(r_{i}, a_{i}\right)>0$ and $y_{a}^{*}\left(r_{i}, a_{i}\right)>0$. The expression for $y^{*}$ informs us that the likelihood of total destruction increases with $\theta N, r_{i}$, and $a_{i}$ and decreases with $A$ and $d$. $y^{*}$ can further be expressed as a linear function of $f_{i}^{\max }$. In other words, all the factors that increase $f_{i}^{\max }$ also increase the likelihood of total destruction. We will return to this issue below.

Formally, we can summarize the findings above as

$$
f_{i}^{*}=\left\{\begin{array}{c}
\tilde{f}_{i} \text { iff } y^{*}\left(r_{i}, a_{i}\right)>0 \\
f_{i}^{\max } \text { iff } y^{*}\left(r_{i}, a_{i}\right) \leq 0 \\
0 \text { iff } f_{i}^{\max } \text { does not exist. }
\end{array}\right.
$$

One of the main variables of interest in the empirical section is the size of the village population that is displaced as a result of the attack. This number equals $\rho\left(f_{i}^{*}\right) L_{i}$. From the model, we can solve for the equilibrium level of displacement by inserting the optimal fighting efforts from (8) into (2):

$$
\rho\left(f_{i}^{*}\right) L_{i}=\left\{\begin{array}{c}
L_{i} \text { iff } f_{i}^{*}=\tilde{f}_{i} \\
\left(1-\sqrt{\frac{A}{\theta N r_{i}^{\alpha} a_{i}^{1-\alpha}}}\right) L_{i} \in\left(0, L_{i}\right) \text { iff } f_{i}^{*}=f_{i}^{\max } \\
0 \text { iff } f_{i}^{*}=0
\end{array}\right.
$$

There are thus three main outcomes: Either that the village is completely abandoned (and all resources are captured or destroyed), or that an attack occurs that results in the displacement of a certain part of the population, or that the village is not attacked at all and that nobody flees. The only sources of variation across villages among these determinants of attacks (except the size of the village population $L_{i}$ ) are resources $r_{i}$ and the proportion of targeted groups $a_{i}$. The expression in (9) shows that the intensity of attacks increases with $a_{i}$ and with $r_{i}$.

In figure 2, we show a simulation of the relationship between $\rho\left(f_{i}^{*}\right)$ and $a_{i}$ at varying levels of $\alpha$, assuming $A / \theta N=1 / 10, r_{i}=1 / 5$, and $d=0.62 .{ }^{22}$ The thin relatively flat line shows the case when $\alpha=9 / 10$ so that preferences for ethnic cleansing are very weak. In this case, the proportion fleeing/the level of destruction is largely unresponsive to $a_{i}$. The

\footnotetext{
${ }^{22}$ A similar model has not been simulated in the literature before and the choice of parameter values is arbitrary.
} 
responsiveness increases when $\alpha=1 / 2$ as in the thick black line. When preferences for ethnic cleansing are strong as shown by the dotted line $(\alpha=1 / 10)$, then the optimal level of attack intensity is very sensitive to $a_{i}$ and it is the only case when the critical threshold is reached so that $\rho\left(f_{i}^{*}\right)$ jumps to unity. ${ }^{23}$

\subsection{Interpretation and empirical predictions}

If we translate the model to a Darfuri context, the attackers are the combined forces of the Janjaweed militia and the government army and the prey is the individual local villages that they attack. We would argue that our model can be used to explain two things: Firstly, why did the massive wave of attacks happen in 2003? Our interpretation, more fully developed in Olsson (2009), is that climate change and land deterioration had worsened conditions for peaceful agriculture since the 1970s, hence causing a lowering of $A$ and an increase in the marginal utility of fighting for the Arabic members of the Janjaweed (eq. (5)). However, as argued by Kevane and Gray (2008), this can not be the only explanation since there is no sign of any dramatic decline in rainfall in the years prior to 2003. Furthermore, a dry period should decrease resources per capita $r_{i}$ and hence reduce the risk of conflict.

The ideology and propaganda of Arabization, practiced by the government in Khartoum, presumably led to that the combined Janjaweed/government forces had a strong preference for ethnic cleansing, i.e. a low $\alpha .{ }^{24}$ From summer 2003, there was further a sudden increase in $\theta$, resulting from the government's policy to help the militias with fighter airplanes, helicopters, and army intelligence. In terms of our model, this should have led to a general boost in optimal levels of predatory fighting effort (eq. (6)). Without this active ideological and military government support, it is highly unlikely that the Janjaweed fighters would have committed violence on such a massive scale against their African neighbors.

However, these factors are constant across villages and do not explain why individual villages were attacked or destroyed. The main dependent variable in the empirical section is a binary dummy for whether villages are destroyed or not. In our theoretical framework, this choice is determined by the sign of $y^{*}\left(r_{i}, a_{i}\right)$ in (7), which we consider to be a latent variable that we try to estimate in the empirical section. The marginal impact of $a_{i}$ is

$$
\frac{\partial y^{*}\left(r_{i}, a_{i}\right)}{\partial a_{i}}=(1-\alpha) L_{i} \sqrt{\frac{A r_{i}^{\alpha}}{\theta N a_{i}^{1+\alpha}}}>0 .
$$

The regression coefficient for $a_{i}$ is thus expected to be positive and to give an indication of $1-\alpha$, the underlying preference for ethnic cleansing. Note also that the cross-derivative is $y_{r a}^{*}\left(r_{i}, a_{i}\right)>0$, i.e. that the probability of attacks motivated by ethnic cleansing should be greater if the village is well endowed with natural resources. It is further easy to

\footnotetext{
${ }^{23}$ In the particular example, this happens at a level of $a_{i} \approx 0.8$.

${ }^{24}$ As documented by Hagan and Rymond-Richmond (2008), the perpetrators of the attacks used a terminology that suggested a racial dehumanization of the African population.
} 
demonstrate that $y_{r}^{*}\left(r_{i}, a_{i}\right)>0$. In terms of our Darfuri context, once the Janjaweed was mobilized and ready, they should thus in particular target villages with either a high fraction of population from the three rebel tribes Fur, Masalit, and Zaghawa $\left(a_{i}\right)$, and/or with a great level of resources per capita $\left(r_{i}\right)$. These are the main hypotheses that we test in the empirical section.

\section{Empirical analysis}

\subsection{Data collection}

The main data source to our empirical analysis comes from international organizations operating in the area. ${ }^{25}$ In 2004/2005, while participating in provision of emergency assistance and protection interventions, these organization(s) undertook a return-oriented profiling exercise in Southwestern Darfur to help understand the complex picture of displacement that the 2003 crisis had created and to support war affected communities, sustain voluntary return and prepare the ground for an eventual voluntary return of a large number of IDP's and refugees to their villages of origin. An important objective of the data collection was to provide reliable intelligence to all emergency organizations in the area.

The profiling was designed to obtain a comprehensive picture of both the current and pre-conflict situations. Addressed information includes: Typologies of settlements (abandoned, and destroyed), the population and ethnic compositon of the villages monitored, relations between the different ethnic groups, land and movement features. Post-conflict qualitative sectoral information on access to health, education, water facilities were covered in the study. Nomadic settlements were also profiled to determine the needs and main concerns of the Arab population. Pre-conflict situations refer to the situation by early 2003, whereas the latest information about the current situation has November 30, 2005 as the oldest date and June 2008 as the most recent date (the median village had its latest visit in October, 2007).

Out of the seven localities of West Darfur state, the data collection covered parts of the Habila, Mujakar, WadiSaleh and Zalingei localities in the south, focusing on the areas of potential return of refugees currently being assisted in Chad. There are eight administrative units in these localities with a total area of approximately 25,000 sq km (almost equivalent to the size of Belgium and roughly 5 percent of Darfur's total territory). We inferred from correspondence with the data collecting staff that their intention has consistently been to gather information from all villages in the area except in limited cases of exclusion of villages might have happened due to lack of roads as well as the security situation, which did not allow the team to be aware of the very existence of some

\footnotetext{
${ }^{25}$ Given the current security situation in Darfur, we have agreed not to disclose the identity of the organization(s) that have provided the data that our study builds upon. Until the situation in the area improves, more details about the data will only be communicated through personal correspondence with the authors.
} 
settlements. Some secondary towns like Forobaranga and Habila are also included, whereas major towns like Garsila and Zalingei are not included. Figure 3 gives a general overview of the area and figure 4 shows the geographical distribution of surveyed settlements. All in all, our base sample consists of 530 settlements ${ }^{26}$ with a total population of approximately 792,000 people before the conflict. ${ }^{27}$

Visiting the target villages, the team collected information on: the location and general situation of the place, detailed information on formal and informal authorities from whom the teams obtained the information, a retrospective assessment of the composition of ethnicities before the crisis, and different specific sections covering health, education, vulnerable persons in the community, water, shelter, accessibility, security, economic situation, land ownership. In addition to speaking with sheiks and other traditional and administrative authorities, the teams were instructed to verify the information they gathered with people in the market and other ordinary residents of each village. Where a location had an international presence, the team also crosschecked information with that organization. Upon return from each mission, the team had three-day debriefing sessions with other staff to compile the data and identify the main issues and trends that emerged from the information gathered. This was followed by a one-day debriefing with two staff members from another organization in the area.

The data referred to above contains few useful proxies for natural resources, which is a key variable in our model. The most important resource in Darfur is land. An ideal variable for our empirical analysis should be able to capture both the quantity and the quality of lands in each village. Water availability is obviously a key determinant of the quality of land. As a proxy for access to surface water, which is the most important source of water in Sudan, we have assembled data on geographical distance (in kilometers) from each village to the nearest major wadi (at least 100 meters in width) by using satellite images in Google Earth. ${ }^{28}$ Wadis are seasonally dry rivers where water is usually available beneath the ground. In Darfur, as well as in many other parts of the Sahel, access to the wadis are important both for cultivators and for livestock herders (UNEP, 2007).

We have also used data on average rainfall, vegetational cover, temperature, and inherent soil quality from FAO (1998). ${ }^{29}$ Unlike our proxy for distance to major wadi above, these variables are only available on an aggregated level for six climate zones and hence only have six units of variation. On the other hand, rainfall and temperature do not display much variation in our rather small sample area, as will be discussed further below.

The rural population is also dependent on health care and education which is typically

\footnotetext{
${ }^{26}$ The sample originally contained 562 villages. 20 villages in the original sample had an inconsistent share of inhabitants. Their ethnic compositions fail to add up to one and no logical explanation is provided for why it is so. As ethnic composition is our primary source of information for identifying African and Arab predominated villages, we excluded these villages from our analysis. 12 other villages had no population before the conflict. The final sample size that our study bases on thus contains 530 villages.

${ }^{27}$ We have reached this figure by multiplying the total number of households 143,938 with an assumed average size of 5.5 individuals, which was the average household size in a survey on the region collected by Deporteere et al (2004). The area sampled has roughly 12 percent of the total population in Darfur.

${ }^{28}$ See Appendix A for an example of how this measure has been constructed.

${ }^{29}$ The averages were calculated for the time period 1982-90.
} 
provided in local administrative centers. For each village, we have therefore calculated the geographical distance to its administrative center, as well as to the major towns El Geneina, El Fasher, and Nyala, using latitude and longitude coordinates in combination with the great circle formula for calculating geodesic distances. We imagine that the closer a village is to an administrative center, the better its access to public goods like health and schools but also to police and courts. On the one hand, access to public goods should make the village a more attractive prize for the predators. On the other hand, proximity to police and courts in the centers could also discourage attacks. The hypothesized direction of the net effect is unclear.

Among the geographical control variables is altitude above sea level, which we have gathered for each village from satellite maps in Google Earth. 'Mountainous terrain' is an often used variable in the empirical conflict theory literature since it is believed to be positively associated with rebel activities (Collier and Hoeffler, 2004). Our altitudevariable is meant to serve as a proxy for mountainous terrain.

In order to control for the influence of the situation in each village's nearest neighbourhood, we have further divided the region into 0.1 latitude degree by 0.1 longitude degree grid cells. In either north-south or east-west direction, a 0.1 degree distance is equivalent to about 10-11 kms so that each grid cell represents a neighbourhood or 'virtual local region' of 100-121 sq km. ${ }^{30}$ We found in total 151 populated grid cells and then estimated the number of destroyed villages, the total population, the total number and proportion of people fleeing, and the ethnic proportions in each cell. For each of the 530 individual villages, there is thus both an observation of for instance total population in the village, as well as the total population in the grid cell to which the village belongs.

\subsection{Descriptive statistics}

Table 1 shows the ethnic composition in our sample before and after the crisis. The two dominant African tribes, the Fur and the Masalit, made up 54 and 16 percent of the population respectively before the crisis. After the conflict, 47,488 Fur households and 9,490 Masalit households had been displaced from their homes, which means 61.4 percent of the Fur and 41.3 of the Masalit. None of the other tribes experienced similar losses. The Arab tribes Meseriya, Salamat, and Bani Hallba experienced population gains by 23.9, 68.9, and 70.9 percent respectively. Out of the five remaining 'New African' groups, the population size of Tama and Gimier decreased while it increased for Borgo, Dajo and Singar. The net decline in population in the area amounts to 47,388 households (or roughly 260,000 individuals).

Our main outcome variable in the empirical analysis is destroyed, which is a dummy value taking the value 1 if all inhabitants fled and the village itself was destroyed. Nondestroyed villages include nomadic settlements, abandoned and inhabited villages, IDP

\footnotetext{
${ }^{30}$ A similar grid cell methodology is used in Buhaug and Röd (2006) where $100 \mathrm{~km}$ by $100 \mathrm{~km}$ cells in Africa are the basic unit of observation. See Appendix B for a map of the geographical distribution of the grid cells.
} 
sites and secondary towns. Alternatively, we constructed a binary variable destroyed_2 with value 1 for villages either destroyed or abandoned villages and zero otherwise. Among the 530 villages in the sample, 327 were found to have been destroyed or abandoned, while 203 villages were neither destroyed nor abandoned.

Figure 5 reveals that there is an overwhelming predominance of people from Fur, Masalit and Zaghawa in the villages that were destroyed, i.e. the main ethnic groups from which the African rebel groups are formed. It should be emphasized that the variable rebeltribes measures the proportion of civilian households of Fur, Masalit, and Zaghawa in each village. The actual rebel fighters may or may not be part of the village populations.

The figure shows that destroyed or abandoned villages on average hosted 88 percent of its population from these tribes. On average, destroyed villages only hosted 11 percent of the 'new' African tribes who migrated from Chad and northern Darfur due to drought of 1970s and 1980s. This includes Tama, Gimir, Mararit, Eringa, Kajaksa, Borgo, Mesiria Jabal, Mimì, Singar, Dajo and Falatta. The destroyed villages in the area were almost exclusively populated by people of some African origin. Only one village with an Arab population was destroyed and the average non-destroyed village hosted about 55 percent Arabs and only about 19 percent from the three rebel tribes. Share of Arab inhabitants is constructed by adding the share of 31 tribes such as Bani Habilla, Hiamat, Mahmid, Meseriya, Rezigat and Salamat.

It should be mentioned though that there is substantial residential segregation in the area. Figure 6 shows the frequency distribution of rebeltribes over the 530 villages. The most typical pattern is that there are either no Fur, Masalit, or Zaghawa in a village (rebeltribes $=0$ ) or that all residents belong to these tribes. As the figure shows, 277 villages in the area had a share of rebeltribes larger than 95 percent.

Figure 4 shows the geographic distribution of destroyed and non-destroyed villages. A striking observation is that most of the destroyed villages have non-destroyed villages as close neighbours, which seems to suggest careful discrimination concerning what villages to attack based on other aspects than geography or land quality.

Table 2 shows the descriptive statistics of the data used in the empirical analysis. Apart from destroyed and destroyed_2, we also use the (logged) number of households fleeing (peoplefled) as a dependent variable. A noteworthy feature is that out of an average population of 270 households before the conflict (popsize), as many as 198 (or around 73 percent) would typically flee.

Among the resource variables, average distance to a major wadi (d_wadi) is 6.38 kilometers, whereas the average level of annual rainfall (rainfall) is only about $705 \mathrm{mms}$. Vegetation is a measure of the intensity of vegetation (NDVI). Temperature is simply average temperature in Celsius degrees, ranging from 23 to 26.8 degrees, and soilquality is an ordinal variable taking discrete values in the range 1-4 where 4 indicates the best soils. ${ }^{31}$ Since all these variables are correlated and only have six units of variation (since

\footnotetext{
${ }^{31}$ soilquality is ranked based on established relationships between soil properties, soil classification unit names, and other factors such as texture, slope and phase.
} 
our surveyed area comprises six FAO climate zones), we also calculated the first principal component of $d_{-}$wadi, rainfall, vegetation, temperature, and soilquality for each village. The resulting index, pcnatres, is intended as an aggregated index of available natural resources.

The mean distance to an administrative center $\left(d_{-}\right.$admin $)$is 26.5 kilometers. Popsize measures population size (number of households) whereas $n$ popsize is the size of the population in the own grid cell and should be thought of as population density. The average grid cell population of 1510 households implies that the average population density, given that the area is populated, is about 80 people per sq km. ${ }^{32}$ In this last category of variables, we also include geographical and other indicators. The average number of either destroyed or abandoned villages in the grid cells ( $n_{-}$destroyed_2) is 3.4, whereas the maximum is 13 (see the figure in appendix B for the geographical distribution of destroyed villages). Almost 1200 households typically flee from each of our 151 populated neighbourhoods ( $n$ _ peoplefled). The average village in the sample is further located at an altitude of about 700 meters above sea level.

\subsection{Empirical strategy}

The main dependent variable in our empirical analysis is a binary indicator $y$ for whether villages are destroyed/abandoned or not. The key predictions of our theoretical model emerge from (7) where it is shown that predators will destroy if $y^{*}>0$. In line with the argument there, we will regard $A, \theta$, and $N$ as deep parameters which influenced the general decision by the Janjaweed to take up arms but which do not display any local variation and thereby do not determine what village to destroy within our sampled region. The primary sources of local variation are instead the proportion of targeted groups $a_{i}$ and resources per capita $r_{i}$.

More formally, we estimate a probit model

$$
\operatorname{Pr}(y=1 \mid x)=\operatorname{Pr}\left(y^{*}>0 \mid x\right)
$$

where $y^{*}$ is a latent, unobserved variable that we estimate by making the simplified assumption that

$$
y^{*}=\beta_{0}+\beta_{1} \cdot \text { Ethnic }+\beta_{2} \cdot \text { Resources }+\mathbf{C}^{\prime} \boldsymbol{\beta}_{3}+\epsilon .
$$

The dependent discrete variable $y$ is either destroyed or destroyed_2. Ethnic is a vector containing our measures of the proportions of the targeted and non-targeted populations before hostilities, Resources include our proxies for resources per capita $r_{i}, \mathbf{C}$ is a vector of other relevant control variables, and $\epsilon_{i}$ is a normally distributed error term. In line with the comparative static in (10), we interpret the size of $\beta_{1}$ to reflect the strength of preferences for ethnic cleansing $1-\alpha$. A $\beta_{1}$ significantly larger than zero should thus

\footnotetext{
${ }^{32} 1510$ times household size 5.5 divided by grid cell size $100 \mathrm{sq} \mathrm{km}$.
} 
imply that $\alpha<1$. Equivalently, $\beta_{2}$ should contain information about the preference for resource capture.

To be more specific, Ethnic includes our main variable rebeltribes showing the proportion of the population among the three targeted tribes before the conflict, as well as the share of Arabs (arabs). The vector of resource variables includes d_wadi, as well as our crude proxies for rainfall, vegetation, temperature, and soilquality.

C sometimes includes village size in number of households before the conflict popsize (the equivalent of $L_{i}$ in our model), $d_{-}$admin, and other geographical variables. It also includes proxies for conflict intensity in the neighbourhood to control for local spillover effects, and interaction terms between Ethnic and Resources.

Our empirical analysis also attempts to estimate a variant of (9) by using a continuous variable measuring the log of total number of households fleeing, peoplefled (capturing $\rho\left(f_{i}^{*}\right) \cdot L_{i}$ in the model). We estimate this by OLS and the basic econometric model is the same as that in (12).

A few remarks are in order. Firstly, we recognize the possibility that Ethnic and Resources are correlated, which could result in colinearity and inflated standard errors. Fortunately, we found a very weak correlation between rebeltribes and our resource variables (-0.13 with $d_{-}$wadi, -0.17 with rainfall, -0.09 with vegetation, -0.11 with temperature, and -0.14 with soilquality).

Secondly, in micro studies like these, it is inevitable to discuss potential problems of sample selection bias. There are at least three possible sources of selection bias: (i) The data collection might focus on villages which are potentially returnable places for displaced people, (ii) on villages affected by the conflict, and (iii) on predominately African villages. The primary aim of the data collecting organization(s) is to support war affected communities and prepare the ground for an eventual voluntary return of IDP's and refugees to their villages of origin. Given their objective and the complexity of conflict situations, we acknowledge the difficulty of humanitarian organizations to collect a representative sample. Any type of selection bias introduced due to this can be taken as a limitation of this study.

However, the latter types of selection bias are of lesser concern since every village in this sub-region of west Darfur, including Habila, Mujakar, WadiSaleh and Zalingei localities, is supposed to be covered. In addition, both African villages and nomadic settlements, predominated by Arabic nomads, are covered in the data collection with the intention of understanding both affected villages and the needs of nomadic population. Figure 4 also reveals that destroyed and non-destroyed villages are geographically distributed very close to each other with no obvious systematic selection of villages.

The third econometric concern is the reliability of the information gathered from formal and informal administrative authorities. Measurement error in the calculation of the shares variables would introduce an attenuation bias on the coefficient for share of ethnic groups. This is of lesser concern to us as the data collection involved a number of crosschecking with people in the market, other ordinary residents of each village and 
international organizations where present to verify the information gathered.

A fourth potential issue is spatial autocorrelation, i.e. that conflict intensity in village $i$ does not only depend on village specific characteristics but also on local spillover effects. We believe that our use of average levels from 10x10 km grid cells as explanatory variables should account for most of these effects.

\subsection{Regression results}

The first set of regressions are shown in table 3 . The main result in these binary probit regressions is immediately clear: The estimate for the proportion of the targeted ethnic groups rebeltribes is always positive and strongly significant, regardless of whether we use destroyed or destroyed_2 as the dependent variable. ${ }^{33}$ The marginal effects, evaluated at the mean and based on the specification in column (3), are displayed in table 4 for selected variables. Given the ethnically segregated pattern of settlement, the most interesting result is probably that a village that has a homogeneous rebeltribes-population faces 71 percent higher predicted risk of being destroyed than a village without any Fur, Masalit, or Zaghawa households ( $\min ->\max =0.71$ ). When the proportion of arabs is included, it always has a negative and strongly significant estimate.

In columns (5)-(7) of table 3 , we see that the significance of the parameter estimate for rebeltribes survives when we include an interaction term between rebeltribes and our composite indicator of natural resources pcnatres. A particularly interesting finding is the positive and significant coefficient for rebel_natres in columns (5)-(6), indicating that the attackers are interested in destroying villages with resources mainly when there are rebel tribes around. The positive estimates for rebeltribes* ${ }^{*}$ cnatres are also well in line with the prediction from the theoretical section. In columns (7) and (9), however, the estimate is not significant.

Our primary resource proxy, $d_{-} w a d i$, is always negative, as predicted, but only significant in column (1) when no other resource variables are included. The marginal effect shown in table 4 is rather small; a one standard deviation increase $(7.93 \mathrm{~km})$ around the mean level (6.38) decreases the probability of attack by 4.7 percent. Among the other resource variables, more rainfall always increases the risk of attack, whereas more vegetation, somewhat surprisingly, decreases the risk of attack. Temperature and soilquality also have positive coefficients in column (3). As an example of their marginal effects, we can infer from table 4 that an increase in annual rainfall from the minimum $500 \mathrm{mms}$ to the maximum $730 \mathrm{mms}$ should increase the risk of destruction by roughly 31 percent. The composite indicator pcnatres is significant in (4) but not in (5)-(7) when the interaction term with rebeltribes is included.

Distance from administrative center, $d_{-} a d m i n$, is usually positive and sometimes significant. This appears to suggest that the Janjaweed prefer to attack more remote villages,

\footnotetext{
${ }^{33}$ All regressions use robust standard errors except in column (3) where standard errors are clustered on the basis of the six climate zones that make up the units of variation in rainfall, vegetation, temperature and soilquality.
} 
possibly to avoid interference with local authorities or eventual police forces in the centers. A one standard deviation increase in $d_{-}$admin (17.26) implies an increase of about 9.9 percent in the predicted probability of destruction.

The size of the population, popsize, is always negative but only significant in (8). Given that we control for resources, we interpret any relationship between village size and likelihood of attacks as working through larger labor force to defend against village attacks. It is further interesting to note that local population density, n_popsize, is negative and significant in (7). Thus, all else equal, the attacking militias seem to be more destructive in less densely populated areas. Not surprisingly, the number of villages destroyed in the nearest neighbourhood, $n_{-}$destroyed and $n_{-}$destroyed_2, are positive and strongly significant throughout, suggesting local spillover effects. ${ }^{34}$

In the table in Appendix $\mathrm{C}$, we have included additional resource variables from FAO (1998) in the probit regression such as a dummy for the suitability for growing crops (cropsuit), the livestock to crop-ratio (livestock_crop), average percentage of cattle in the herd composition (cattle), readily available soil moisture (soilmoisture), and a proxy for the access to water points (water_points). These alternative variables rarely display much explanatory power and the coefficient for rebeltribes is more or less unaffected.

Table 5 shows the OLS results when we use the number of households fleeing, peoplefled (in logs), as the dependent variable. In columns (1)-(6), we exploit the full sample including the 130 villages from which no one has fled. In columns (7)-(8), we only include the 400 villages from which a positive number of people have fled to check if the effects are qualitatively different. ${ }^{35}$

Controlling for the initial size of the population, the share of Arab neighbors, natural resources, and geographical variables, the estimate for rebeltribes is consistently positive and significant. Figure 7a shows the conditional correlation between log peoplefled and rebeltribes on the basis of the specification in column (3). A calculation of the marginal effects in column (3) shows that half a standard deviation increase in the proportion of Fur, Masalit, and Zaghawa in the population (0.227) would imply an additional 17.75 households fleeing. ${ }^{36}$ The marginal effect of an increase in rebeltribes turns out to be very similar even when we exclude villages without any fleeing households as in column (8). ${ }^{37}$ As expected, the coefficient for arabs is negative and significant in columns (2)-(6) and (8) and the marginal effects are even higher than for rebeltribes.

$d_{-}$wadi is negative and significant in columns (1)-(3). Figure $7 \mathrm{~b}$ shows the conditional scatter plot based on (3) and it is immediately clear that the marginal effect of $d_{-}$wadi

\footnotetext{
${ }^{34}$ We recognize of course that there is an endogeneity problem in the sense that the destruction of any individual village is measured both by destroyed and $n_{-}$destroyed.

${ }^{35} \mathrm{We}$ also tried a hurdle model where villages with any fleeing population were coded as 1 in a binary probit, and then ran OLS regressions for log peoplefled on the explanatory variables for the 400 villages with fleeing households "selected" in the first stage. We omitted these probit results since they showed very similar results as those in table 3 .

${ }^{36}$ We calculate this effect as $\beta_{1} \cdot \exp \left(\beta_{0}+\beta_{1} \cdot\right.$ Ethnic $\left.+\beta_{2} \cdot \operatorname{Resources}+\mathbf{C}^{\prime} \boldsymbol{\beta}_{3}\right)$ with all included independent variables held at their mean.

${ }^{37}$ The implied marginal effect of rebeltribes is 78.14 in column (3) and 77.08 in column (8). Since the samples are different, the numbers are calculated using different means.
} 
is smaller than for rebeltribes. Half a standard deviation increase in $d_{-}$wadi $(3.96 \mathrm{~km})$, evaluated at mean levels on the basis of (3), implies a decrease of only 2.08 households fleeing. The variable is not significant in the last three columns. An equally dimensioned increase in rainfall (31.55 $\mathrm{mms}$ ) would increase the number of households fleeing by 4.87 on the basis of column (3). Also vegetation, temperature, and soilquality are significant in column (3), but the sign is now negative for soilquality, which is surprising. The composite indicator pcnatres is never significant.

Among the remaining variables, only log popsize and our population density indicator $\log n_{\text {_ }}$ popsize display any significant effects. The positive estimate of $\log n \_$popsize could suggests that people are more inclined to flee in more densely populated areas, even though a high density makes total destruction less likely according to the results in table 3. $d_{-}$admin is only significant in column (1).

In summary, we would argue that the regressions above demonstrate that the ethnic composition of the village population is the most powerful predictor of village destruction and of the extent of population fleeing. Our major resource variable, d_wadi, has a negative but not consistently significant impact on the intensity of attacks, whereas areas with more rainfall but less vegetation are more likely to be targeted.

\section{Conclusions}

The main question addressed in this article is whether the conflict in Darfur is driven by attempts of ethnic cleansing or by a struggle for natural resources. Both are a priori plausible and often proposed reasons for the war. In this paper, we have offered a theoretical framework for analyzing the choice to pursue ethnic cleansing. Our empirical analysis, based on a sample of 530 villages in the southwestern part of the region, very clearly suggests that the combined Janjaweed/government attacks are primarily explained by the proportion of the rebel tribes Fur, Masalit, and Zaghawa in the population, whereas our proxies for resources are less consistently significant and generally have a more modest impact. The inclusion of several geographical control variables do not affect this general tendency in the data. Hence, we draw the conclusion that the conflict in this area of Darfur should primarily be described as an ethnic cleansing campaign, although we cannot rule out that resources have also played a certain role.

Our data also clearly shows that a massive displacement of people has occurred, as well as a major reallocation of land away from the three rebel tribes to Arab and new African ethnic groups. The socio-economic impacts of the ethnic cleansing documented in this study are likely to be substantial and are a natural next step for future research. 


\section{References}

[1] Abdul-Jalil, M.A. (2006) "The Dynamics of Customary Land Tenure and Natural Resource Management in Darfur" Land Reform, 2006/2, 9-23, FAO.

[2] Alesina, A., A. Devleeschauwer, W. Easterly, S. Kurlat and R. Wacziarg (2003) "Fractionalization", Journal of Economic Growth, 8:155-94.

[3] America.Gov (2004) "Powell Reports Sudan Responsible for Genocide in Darfur" $\quad<$ http://www.america.gov/st/washfileenglish/2004/September/20040909115958JTgnilwoD0.5094873.html>, 9 September, 2004.

[4] André, C. and J-P Platteau (1998) "Land Relations Under Unbearable Stress: Rwanda Caught in the Malthusian Trap" Journal of Economic Behaviour and Organization 34, 147.

[5] BBC (2008) "Darfur deaths 'could be 300,000'", BBC News Africa, <http://news.bbc.co.uk/2/hi/africa/7361979.stm>, accessed 2008-04-23.

[6] Bell-Fialkoff, A. (1993) "A Brief History of Ethnic Cleansing" Foreign Affairs, 72(3), 110-121.

[7] Bellows, J. and E. Miguel (2006) "War and Institutions: New Evidence from Sierra Leone" American Economic Review, Papers and Proceedings, 96(2), 394-399.

[8] Blattman and Miguel, E. (2008) "Civil War" forthcoming in Journal of Economic Literature.

[9] Brosché, J. (2008) "Darfur - Dimensions and Dilemmas of a Complex Situation" UCDP Paper No. 2, Dept of Peace and Conflict Research, Uppsala University.

[10] Buhaug, H. and J.K. Röd (2006) "Local Determinants of African Civil Wars, 1970-2001" Political Geography 25(3), 315-335.

[11] Czaika, M. and K. Kis-Katos (2007) "Civil Conflict and Displacement: Village-Level Determinants of Forced Migration in Aceh" mimeo, University of Freiburg.

[12] Collier, P. and A. Hoeffler (1998) "On Economic Causes of Civil War" Oxford Economic Papers 50, 563-573.

[13] Collier, P. and A. Hoeffler (2004) "Greed and Grievance in Civil War" Oxford Economic Papers, 56, 563-95.

[14] Depoortere, E., F. Checchi, F. Broillet, S. Gerstl, A. Minetti, O. Gayraud, V. Briet, J. Pahl, I. Defourny, M. Tatay, and V. Brown (2004) "Violence and Mortality in West Darfur, Sudan (2003-2004): Epidemiological Evidence from Four Surveys" Lancet, 364, October 9, $1315-1320$.

[15] Diamond, J. (2005) Collapse: How Societies Choose to Fail or Succeed, New York: Penguin Group. 
[16] Do, Q.T. and L. Iyer (2007) "Poverty, Social Divisions and Conflict in Nepal" WPS4228, World Bank.

[17] FAO (1998) The Soil and Terrain Database for Northeastern Africa. Land and Water Ditital Media Series, No 2, ISBN 92-5-104078-8.

[18] Fearon, J. and D. Laitin (2003) "Etnicity, Insurgency, and Civil War" American Political Science Review 97, 75-90.

[19] Flint, J. and A. De Waal (2008) Darfur: A New History of a Long War (Revised and Updated), New York: Zed Books.

[20] Grossman, H.I. and M. Kim (1995) "Swords or Plowshares? A Theory of the Security of Claims to Property" Journal of Political Economy, 103, 1275-88.

[21] Hagan, J. and W. Rymond-Richmond (2008) "The Collective Dynamics of Racial Dehumanization and Genocidal Victimization in Darfur" American Sociological Review 73(Dec), 875-902.

[22] Homer-Dixon, T. (1994) "Environmental Scarcities and Violent Conflict: Evidence from Cases" International Security 19(1), 5-40.

[23] ICC (2009) "Case The Prosecutor v. Omar Hassan Ahmad Al Bashir", ICC 02/05-01/09, 4 March 2009, International Criminal Court, <http://www.icccpi.int/iccdocs/doc/doc639078.pdf>.

[24] Kevane, M. and L. Gray (2008) "Darfur: Rainfall and Conflict" Environmental Research Letters 3, 1-10.

[25] Ki Moon, B. (2007) "A Climate Culprit in Darfur" Washington Post, June 16, 2007.

[26] Mann, M. (2005) The Dark Side of Democracy: Explaining Ethnic Cleansing, Cambridge University Press.

[27] Miguel, E., S. Satyanath, and E. Sergenti (2004) "Economic Shocks and Civil Conflict: An Instrumental Variables Approach", Journal of Political Economy 112(4), 725-753.

[28] Murshed, S.M. and S. Gates (2005) "Spatial-Horizontal Inequality and the Maoist Insurgency in Nepal" Review of Development Economics 9(1), 121-134.

[29] Nordås, R. and N.P. Gleditsch (2007) "Climate change and conflict" Political Geography 26, $627-638$.

[30] O'Fahey, R.S. and Tubiana (2009) "Darfur: Historical and Contemporary Aspects" $<$ http://www.smi.uib.no/darfur/A\%20DARFUR\%20WHOS\%20WHO3.pdf>

[31] Olsson, O. (2009) "Market Collapse in Vulnerable Environments: A Model Applied to Darfur", University of Gothenburg, mimeo. 
[32] Olsson, O. and H. Congdon Fors (2004) "Congo: The Prize of Predation" Journal of Peace Research 41(3), 321-336.

[33] Petersen, A.H. and L. Tullin (2006a) The Scorched Earth of Darfur: Patterns in Death and Destruction Reported by the People of Darfur http://www.bloodhound.se/06_04_26_DARFUR_report.pdf, Copenhagen: Bloodhound.

[34] Petersen, A.H. and L. Tullin (2006b) Annexes to report The Scorched Earth of Darfur: Patterns in Death and Destruction Reported by the People of Darfur http://www.bloodhound.se/06_04_12_table1_3.pdf, Copenhagen: Bloodhound.

[35] Petrovic, D. (1994) "Ethnic Cleansing - An Attempt at Methodology" European Journal of International Law 5(1), 342-359.

[36] Prunier, G. (2007) Darfur: The Ambiguous Genocide (Revised and Updated Edition), New York: Cornell University Press.

[37] Sachs, J. (2006) "Ecology and Political Upheaval", Scientific American July, 295(1), 37.

[38] Schubert, R. et al (2008) "Climate Change as a Security Risk", German Advisory Council on Global Change, http://www.wbgu.de/wbgu_jg2007_engl.html.

[39] Schimmer, R. (2008) "Tracking the Genocide in Darfur: Population Displacement as Recorded by Remote Sensing" Genocide Studies Working Paper No. 36, Yale University.

[40] Security Council (2006), "Resolution 1674", S/RES/1674, New York: United Nations.

[41] Turner, M.D. (2004) "Political Ecology and the Moral Dimensions of 'Resource Conflicts': The Case of Farmer-Herder Conflicts in the Sahel" Political Geography 23, 863-889.

[42] UNEP (2007) "Sudan: Post-Conflict Environmental Assessment", United Nations Environmental Programme: Nairobi.

[43] United Nations (2005) "Report of the International Commission of Inquiry on Darfur to the United Nations Secretary General", United Nations: Geneva.

[44] van den Brink, R., D. Bromley, and J.P. Chavas (1995) "The Economics of Cain and Abel: Agro-Pastoral property Rights in the Sahel" Journal of Development Studies, 31(3), 373-399.

[45] Vanrooyen, M., J. Leaning, K. Johnson, K. Hirschfeld, D. Tuller, A. Levine, J. Hefferman (2008) "Employment of a Livelihood Analysis to Define Genocide in the Darfur Region of Sudan" Journal of Genocide Research 10(3), 343-358.

[46] Verwimp, P. (2005) "An Economic Profile of Peasant Perpetrators of Genocide: Micro-level Evidence From Rwanda", Journal of Development Economics 77, 297-323. 
Figure 1: Examples of optimal levels of fighting $f_{i}^{*}$

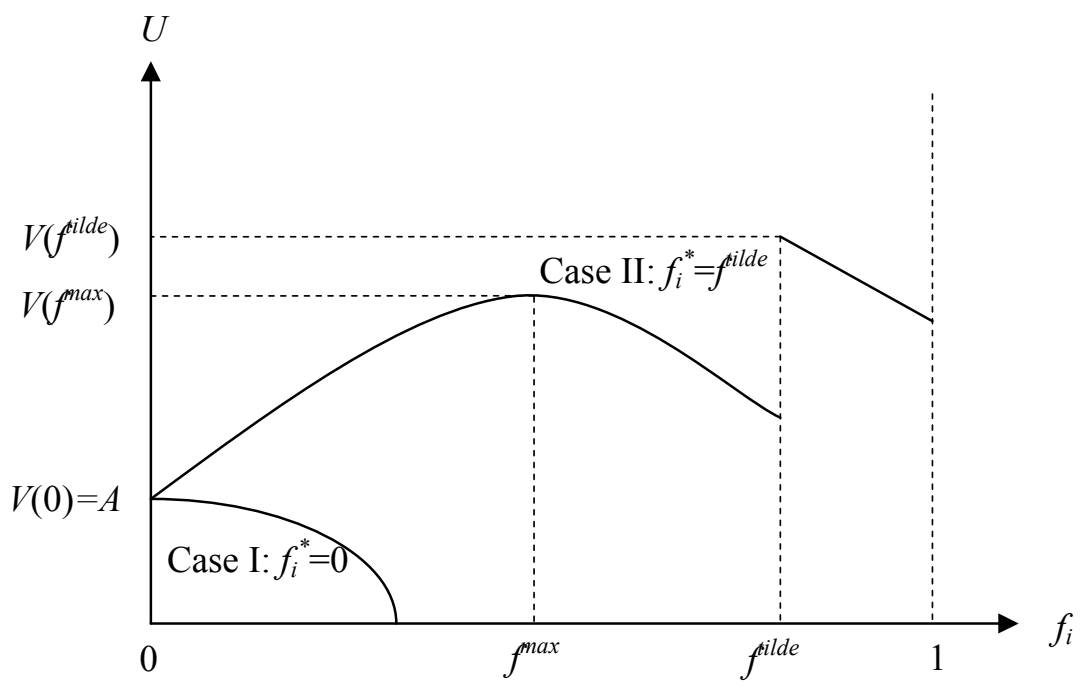

Note: The figure shows utility as a function of predator fighting effort $f_{i}$ in accordance with eqs. (4)-(5). In Case I, the marginal utility of fighting (eq. 5) is negative at all $f_{i} \leq 1$. In Case II, utility reaches a maximum at $f^{\text {max }}$ with an indirect utility level $V\left(f^{\text {max }}\right)$, but $f^{\text {filde }}$ - associated with total destruction of village $i$ - is still the optimal choice of effort. 
Figure 2: Simulated relationship between the equilibrium proportion of the village population fleeing $\rho\left(f^{*}\right)$ (denoted $r h o$ ) and the share of the targeted population $a_{i}$ at different relative preferences for ethnic cleansing.

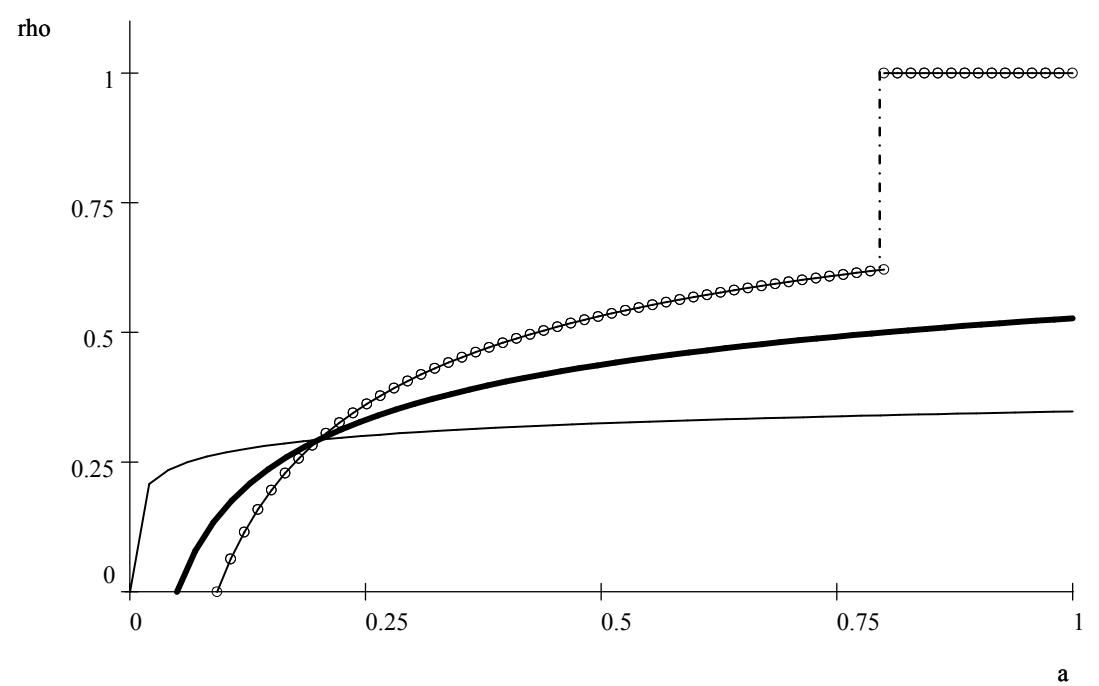

Note: The figure plots equation (9) at varying strengths of preferences for ethnic cleansing $(1-\alpha)$. We assume $A / \theta N=1 / 10$ and $r_{i}=1 / 5$ throughout. The thin flat line illustrates a weak preference for ethnic cleansing $(\alpha=0.9)$. The middle thick curve shows equal preferences for ethnic cleansing and resource capture $(\alpha=0.5)$. The dotted line assumes a strong preference for ethnic cleansing $(\alpha=0.1)$. This line is discontinuous at an assumed critical level $d=0.62$ when the whole village is abandoned. The associated proportion of the targeted group at this level is $a_{i}=0.795$. 
Figure 3: Map of Southwestern Darfur (surveyed area)

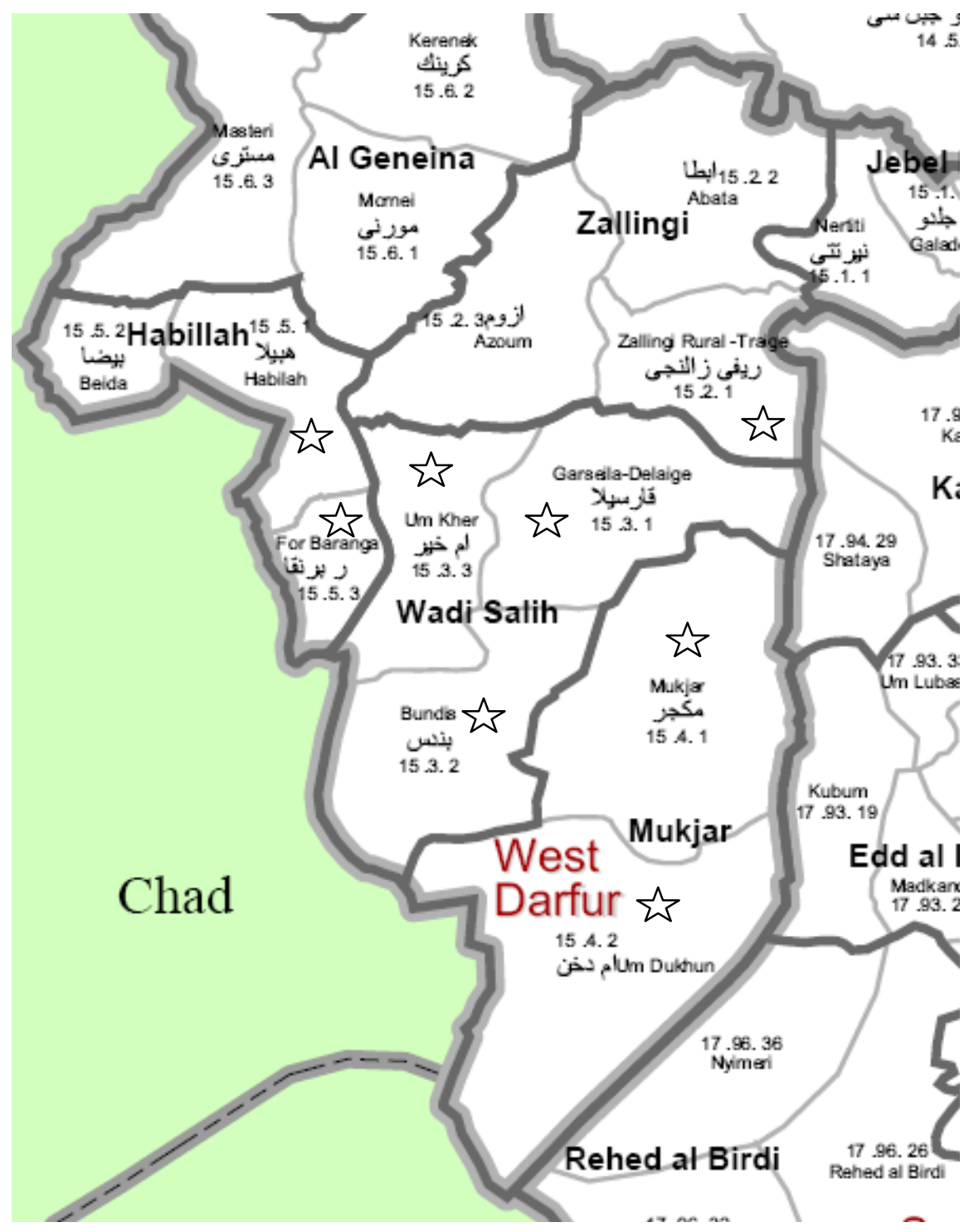

Note: The map shows the eight administrative units (marked by a star) within Habila, Zalingei, Mujakar, and Wadi Saleh localities that are covered in the study. Source: Relief Web (2009) 
Figure 4: Geographical distribution of destroyed and non-destroyed villages in the sample

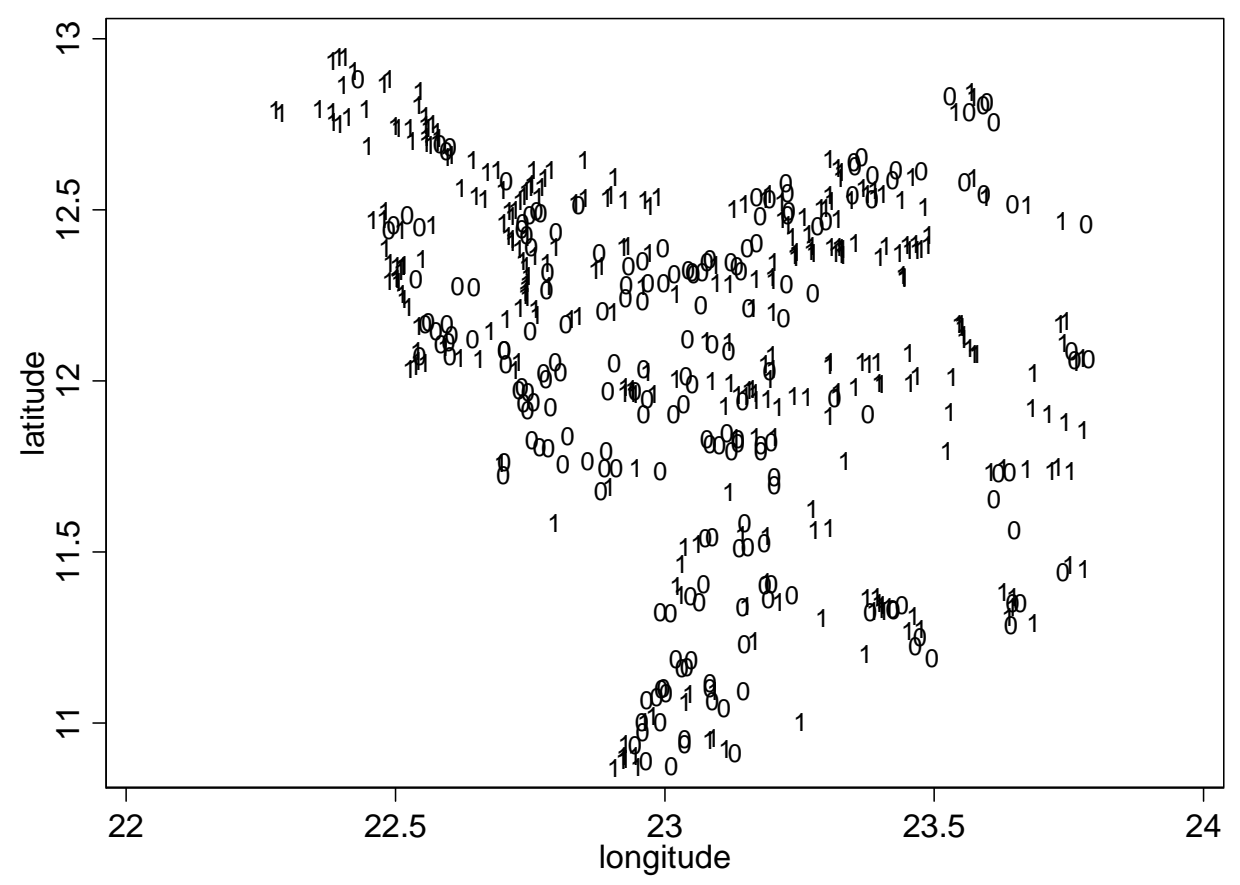

Note: Each number in the figure represents the location of a village. The label " 0 " indicates that the village neither has been destroyed nor abandoned, whereas " 1 " indicates that the village has been either destroyed or abandoned (destroyed_2). 203 settlements were neither destroyed nor abandoned, whereas 327 villages were either destroyed or abandoned. 
Figure 5: Average proportion of ethnic groups before conflict in destroyed and non-destroyed villages

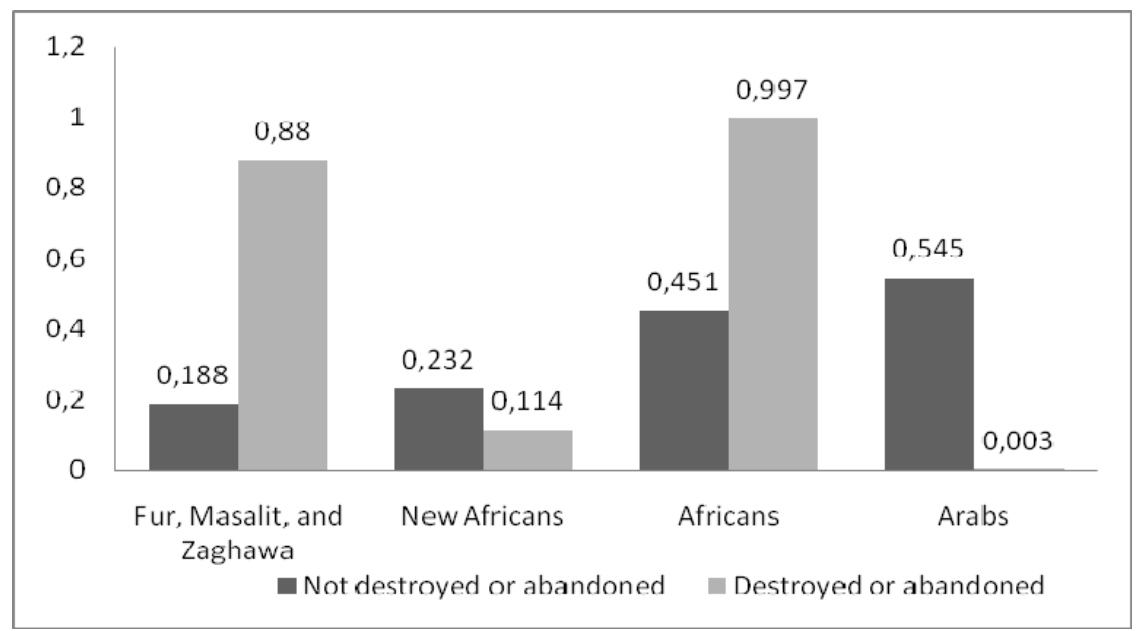

Note: The figure shows the proportion of households from different ethnic groups before conflict in destroyed or abandoned villages (destroyed_2 $=1$ ) or not destroyed or abandoned villages. 203 villages were neither destroyed nor abandoned whereas 327 villages were either destroyed or abandoned.

Source: Own calculation 
Figure 6: Frequency distribution of the proportion of Fur, Masalit, and Zaghawa (rebeltribes) among 530 villages

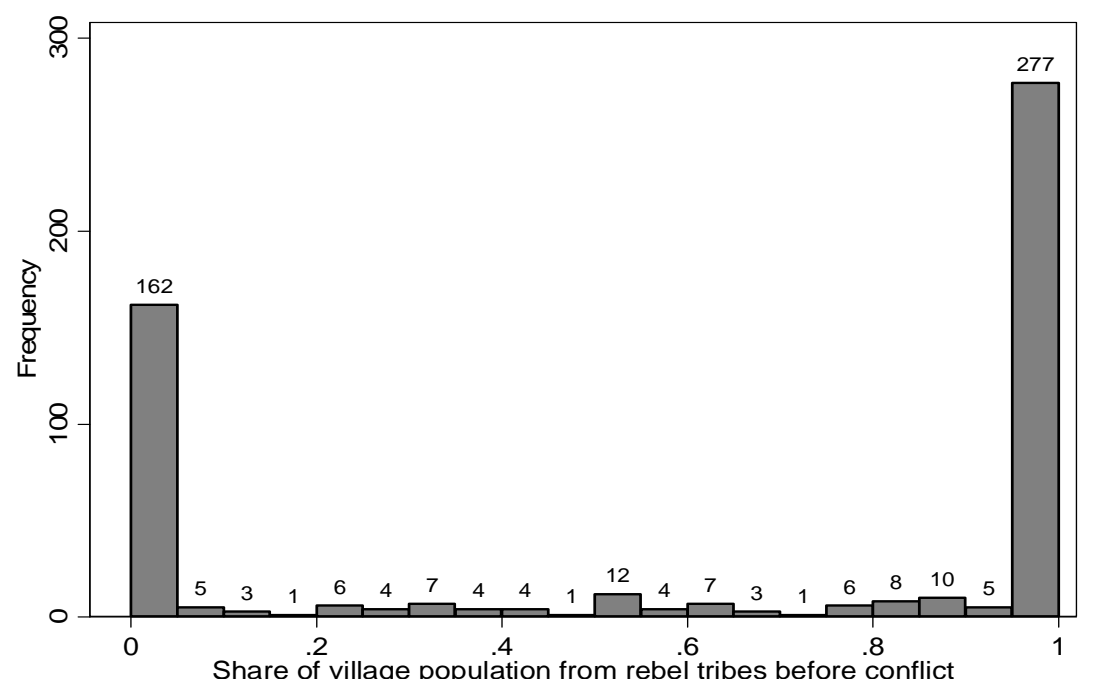

Note: The numbers above each column shows the number of villages within each category. Source: Own calculation 
Figure 7a: Partial relationship between the logged number of households fleeing (log peoplefled) and share of households from rebel tribes in the village population (rebeltribes)

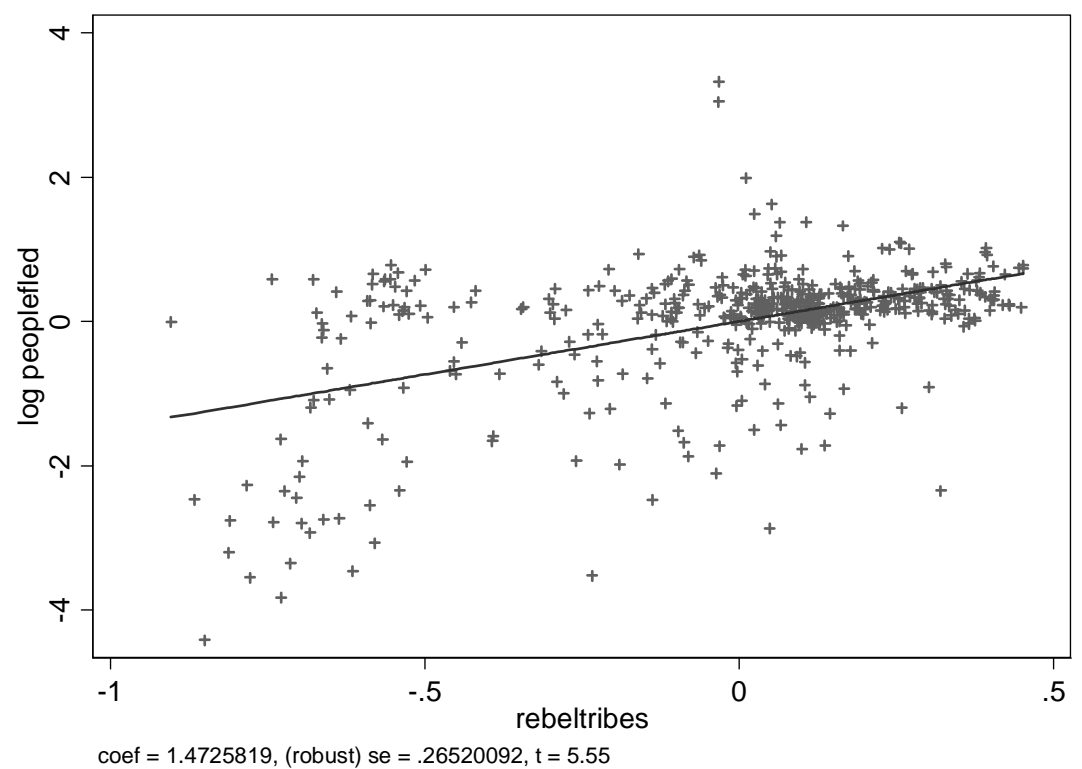

Note: The figure shows the partial relationship between log peoplefled and rebeltribes when using specification (3) in table 5 .

Figure 7b: Partial relationship between the logged number of households fleeing (log peoplefled) and distance to major wadi $\left(d \_\right.$wadi $)$

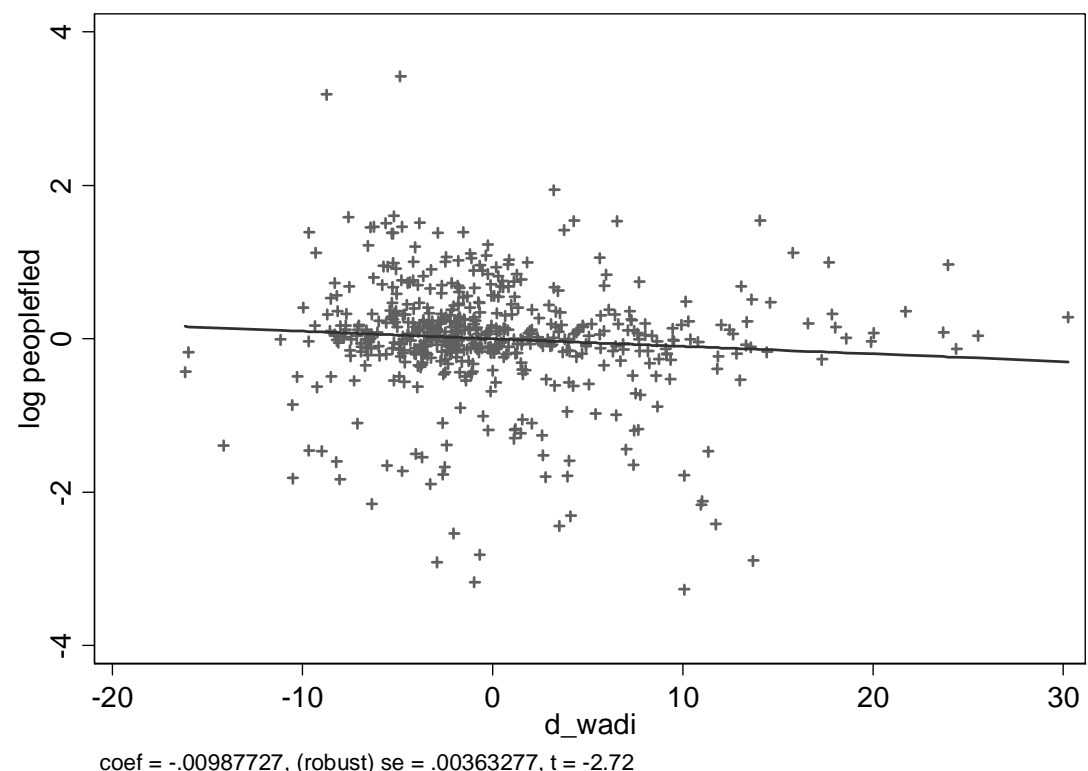

Note: The figure shows the partial relationship between $\log$ peoplefled and $d_{-}$wadi when using specification (3) in table 5 . 
Table 1: Total number of households belonging to the 10 largest ethnic groups before and after the conflict

\begin{tabular}{|c|c|c|c|c|c|c|c|}
\hline $\begin{array}{l}\text { Ethnic } \\
\text { groups }\end{array}$ & $\begin{array}{l}\text { Ethnic } \\
\text { category }\end{array}$ & $\begin{array}{c}\text { No. of } \\
\text { households } \\
\text { before the } \\
\text { conflict } \\
\end{array}$ & Share & $\begin{array}{c}\text { No. of } \\
\text { households } \\
\text { after the } \\
\text { conflict }\end{array}$ & Share & $\begin{array}{c}\text { Change in } \\
\text { no. of } \\
\text { households }\end{array}$ & $\begin{array}{c}\text { Change in } \\
\text { percent }\end{array}$ \\
\hline Fur & $\begin{array}{l}\text { African } \\
\text { (rebel tribe) }\end{array}$ & 77285 & 0.54 & 29797 & 0.31 & -47488 & -61.4 \\
\hline Masalit & $\begin{array}{l}\text { African } \\
\text { (rebel tribe) }\end{array}$ & 22974 & 0.16 & 13484 & 0.14 & -9490 & -41.3 \\
\hline Tama & African & 6784 & 0.05 & 6707 & 0.07 & -76 & -1.1 \\
\hline Dajo & African & 3903 & 0.03 & 4401 & 0.05 & 498 & 12.8 \\
\hline Meseriya & Arab & 3759 & 0.03 & 4656 & 0.05 & 897 & 23.9 \\
\hline Salamat & Arab & 3706 & 0.03 & 6258 & 0.06 & 2553 & 68.9 \\
\hline Borgo & African & 2623 & 0.02 & 3852 & 0.04 & 1229 & 46.9 \\
\hline Singar & African & 2084 & 0.01 & 2867 & 0.03 & 783 & 37.6 \\
\hline Gimier & African & 1879 & 0.01 & 1857 & 0.02 & -22 & -1.2 \\
\hline Bani Hallba & Arab & 1332 & 0.01 & 2277 & 0.02 & 944 & 70.9 \\
\hline Others & Mixed & 17608 & 0.12 & 20393 & 0.21 & 2785 & 15.8 \\
\hline Total & & 143938 & 1 & 96550 & 1 & -47388 & -32.9 \\
\hline
\end{tabular}

Source: Own calculation 
Table 2: Descriptive statistics of variables used in the empirical analysis

\begin{tabular}{|c|c|c|c|c|c|c|}
\hline Variable & Description & Obs & Mean & $\begin{array}{l}\text { Std. } \\
\text { dev. }\end{array}$ & Min & Max \\
\hline \multicolumn{7}{|c|}{ Dependent variables } \\
\hline destroyed & Binary dummy for village destroyed & 530 & .4792 & .5000 & 0 & 1 \\
\hline destroyed_2 & $\begin{array}{l}\text { Binary dummy for village destroyed or } \\
\text { abandoned }\end{array}$ & 530 & .6170 & .4866 & 0 & 1 \\
\hline peoplefled & No. of households fleeing from village & 530 & 198.42 & 433.54 & 0 & 7200 \\
\hline \multicolumn{7}{|c|}{ Ethnic variables (independent) } \\
\hline rebeltribes & $\begin{array}{l}\text { Proportion of Fur, Masalit, and Zaghawa } \\
\text { households before conflict in village }\end{array}$ & 530 & .6152 & .4542 & 0 & 1 \\
\hline arabs & $\begin{array}{l}\text { Proportion of households from Arab tribes } \\
\text { before conflict in village }\end{array}$ & 530 & .2107 & .3995 & 0 & 1 \\
\hline \multicolumn{7}{|c|}{ Resource variables (independent) } \\
\hline d_wadi & $\begin{array}{l}\text { Distance from village to nearest major wadi } \\
\text { (in kms) }\end{array}$ & 530 & 6.38 & 7.93 & .01 & 39.17 \\
\hline rainfall & $\begin{array}{l}\text { Average annual rainfall in mms in village's } \\
\text { climate zone }\end{array}$ & 530 & 704.9 & 63.11 & 500 & 730 \\
\hline vegetation & $\begin{array}{l}\text { Average annual NDVI in village's climate } \\
\text { zone }\end{array}$ & 530 & 0.1745 & .015 & 0.14 & 0.19 \\
\hline temperature & $\begin{array}{l}\text { Annual mean temperature in Celsius degrees } \\
\text { in village's climate zone }\end{array}$ & 530 & 25.34 & .519 & 23 & 26.8 \\
\hline soilquality & $\begin{array}{l}\text { Inherent soil quality in village's climate zone } \\
\text { where low }=1 \text { and low-medium-high }=4\end{array}$ & 530 & 3.57 & .948 & 1 & 4 \\
\hline pcnatres & $\begin{array}{l}\text { First principal component of resource } \\
\text { variables above }\end{array}$ & 530 & 0.017 & 1.580 & -4.43 & 2.48 \\
\hline \multicolumn{7}{|c|}{ Geographical and other variables (independent) } \\
\hline popsize & No. of households before conflict in village & 530 & 269.63 & 536.35 & 11 & 7200 \\
\hline n_popsize & $\begin{array}{l}\text { Total no. of households in } 10 \mathrm{~km} \text { by } 10 \mathrm{~km} \\
\text { neighbourhood (grid cell) }\end{array}$ & 530 & 1510.1 & 1795.4 & 18 & 8917 \\
\hline n_rebels & $\begin{array}{l}\text { Proportion of Fur, Masalit, and Zaghawa in } 10 \\
\mathrm{~km} \text { by } 10 \mathrm{~km} \text { neighbourhood (grid cell) }\end{array}$ & 530 & .6599 & .3308 & 0 & 1 \\
\hline n_destroyed & $\begin{array}{l}\text { Number of villages destroyed in } 10 \mathrm{~km} \text { by } 10 \\
\mathrm{~km} \text { neighbourhood (grid cell) }\end{array}$ & 530 & 2.58 & 2.78 & 0 & 12 \\
\hline n_destroyed_2 & $\begin{array}{l}\text { Number of villages destroyed or abandoned in } \\
10 \mathrm{~km} \text { by } 10 \mathrm{~km} \text { neighbourhood (grid cell) }\end{array}$ & 530 & 3.38 & 2.80 & 0 & 13 \\
\hline $\mathrm{n} \_$peoplefled & $\begin{array}{l}\text { Total no. of households fleeing in } 10 \mathrm{~km} \text { by } \\
10 \mathrm{~km} \text { neighbourhood (grid cell) }\end{array}$ & 530 & 1196.8 & 1756.5 & 0 & 8917 \\
\hline d_admin & $\begin{array}{l}\text { Distance from village to administrative center } \\
\text { (in kms) }\end{array}$ & 530 & 26.80 & 17.26 & 0 & 80.12 \\
\hline d_elgen & Distance from village to El Geneina (in kms) & 530 & 167.8 & 56.5 & 55.4 & 291.4 \\
\hline d_elfash & Distance from village to El Fasher (in kms) & 530 & 310.9 & 40.6 & 213.5 & 408.4 \\
\hline d_nyala & Distance from village to Nyala (in $\mathrm{kms}$ ) & 530 & 211.5 & 38.97 & 123.9 & 300.1 \\
\hline altitude & Altitude above sea level (meters) & 530 & 697.54 & 128.84 & 502 & 1290 \\
\hline latitude & Latitude degree & 530 & 12.08 & .5014 & 10.87 & 12.95 \\
\hline longitude & Longitude degree & 530 & 23.01 & .3584 & 22.24 & 23.75 \\
\hline
\end{tabular}

Sources: All variables are taken or constructed from data collected by international organizations in the area except d_wadi and altitude that were derived from Google Earth, and rainfall, vegetation, temperature, and soilquality that were taken from FAO (1998). The geographical distances from each village to their relevant administrative center d_admin, to El Geneina d_elgen, and to El Fasher $d \_$elfash, were calculated using latitude and longitude coordinates in the great circle formula. 
Table 3: Probability of a village being destroyed

\begin{tabular}{|c|c|c|c|c|c|c|c|c|c|}
\hline VARIABLES & $\begin{array}{c}(1) \\
\text { destroyed }\end{array}$ & $\begin{array}{c}(2) \\
\text { destroyed } \\
\end{array}$ & $\begin{array}{c}(3) \\
\text { destroyed } \\
\end{array}$ & $\begin{array}{c}(4) \\
\text { destroyed } \\
\end{array}$ & $\begin{array}{c}(5) \\
\text { destroyed } \\
\end{array}$ & $\begin{array}{c}(6) \\
\text { destroyed } \\
\end{array}$ & $\begin{array}{c}(7) \\
\text { destroyed } \\
\end{array}$ & $\begin{array}{c}(8) \\
\text { destroyed } 2 \\
\end{array}$ & $\begin{array}{c}(9) \\
\text { destroyed } 2 \\
\end{array}$ \\
\hline rebeltribes & $\begin{array}{c}2.042 * * * \\
(0.151)\end{array}$ & $\begin{array}{c}2.229 * * * \\
(0.358)\end{array}$ & $\begin{array}{c}2.299 * * * \\
(0.377)\end{array}$ & $\begin{array}{c}2.201 * * * \\
(0.157)\end{array}$ & $\begin{array}{c}2.154 * * * \\
(0.159)\end{array}$ & $\begin{array}{c}1.515^{* * *} \\
(0.208)\end{array}$ & $\begin{array}{c}1.898 * * * \\
(0.318)\end{array}$ & $\begin{array}{c}2.712 * * * \\
(0.170)\end{array}$ & $\begin{array}{c}2.444 * * * \\
(0.322)\end{array}$ \\
\hline arabs & & & & & & $\begin{array}{c}-1.607 * * * \\
(0.504)\end{array}$ & $\begin{array}{c}-1.399 * * * \\
(0.524)\end{array}$ & & $\begin{array}{c}-2.145^{* * * *} \\
(0.521)\end{array}$ \\
\hline d_wadi & $\begin{array}{l}-0.0233 * * \\
(0.00928)\end{array}$ & $\begin{array}{l}-0.0113 \\
(0.0112)\end{array}$ & $\begin{array}{l}-0.0151 \\
(0.0122)\end{array}$ & & & & & $\begin{array}{c}-0.0267 * * \\
(0.0107)\end{array}$ & \\
\hline rainfall & & $\begin{array}{c}0.0101 * * * \\
(0.00282)\end{array}$ & $\begin{array}{c}0.00390^{* *} \\
(0.00173)\end{array}$ & & & & & & \\
\hline vegetation & & $\begin{array}{c}-47.66 * * * \\
(15.26)\end{array}$ & $\begin{array}{c}-26.73 * * * \\
(9.559)\end{array}$ & & & & & & \\
\hline temperature & & & $\begin{array}{l}0.393 * \\
(0.221)\end{array}$ & & & & & & \\
\hline soilquality & & & $\begin{array}{c}0.371 * * * \\
(0.110)\end{array}$ & & & & & & \\
\hline pcnatres & & & & $\begin{array}{l}0.260 * * * \\
(0.0636)\end{array}$ & $\begin{array}{l}-0.1067 \\
(0.114)\end{array}$ & $\begin{array}{r}-0.0893 \\
(0.131)\end{array}$ & $\begin{array}{l}-0.0569 \\
(0.197)\end{array}$ & & $\begin{array}{c}0.366^{* *} \\
(0.183)\end{array}$ \\
\hline rebeltribes*pcnatres & & & & & $\begin{array}{c}0.438^{* * *} \\
(0.127)\end{array}$ & $\begin{array}{c}0.385 * * * \\
(0.143)\end{array}$ & $\begin{array}{c}0.223 \\
(0.187)\end{array}$ & & $\begin{array}{l}-0.0844 \\
(0.159)\end{array}$ \\
\hline d_admin & $\begin{array}{c}0.00642 \\
(0.00430)\end{array}$ & $\begin{array}{c}0.00755 \\
(0.00558)\end{array}$ & $\begin{array}{l}0.0146^{* *} \\
(0.00745)\end{array}$ & $\begin{array}{c}0.00698 \\
(0.00427)\end{array}$ & $\begin{array}{l}0.0084^{*} \\
(0.0043)\end{array}$ & $\begin{array}{l}0.00811^{*} \\
(0.00456)\end{array}$ & $\begin{array}{c}0.0110 \\
(0.00687)\end{array}$ & $\begin{array}{l}0.00924 * \\
(0.00527)\end{array}$ & $\begin{array}{l}-0.00154 \\
(0.00734)\end{array}$ \\
\hline popsize & $\begin{array}{l}-9.79 \mathrm{e}-05 \\
(0.000114)\end{array}$ & $\begin{array}{l}-0.000167 \\
(0.000151)\end{array}$ & $\begin{array}{l}-0.000197 \\
(0.000161)\end{array}$ & $\begin{array}{l}-0.000154 \\
(0.000135)\end{array}$ & $\begin{array}{l}-0.00016 \\
(0.0002)\end{array}$ & $\begin{array}{l}-0.000170 \\
(0.000151)\end{array}$ & $\begin{array}{l}-0.000140 \\
(0.000203)\end{array}$ & $\begin{array}{c}-0.000342^{* *} \\
(0.000164)\end{array}$ & $\begin{array}{l}-0.000365 \\
(0.000231)\end{array}$ \\
\hline n_popsize & & & & & & & $\begin{array}{c}-0.00022 * * * \\
(8.04 \mathrm{e}-05)\end{array}$ & & $\begin{array}{l}-9.49 \mathrm{e}-05 \\
(6.73 \mathrm{e}-05)\end{array}$ \\
\hline n_destroyed & & & & & & & $\begin{array}{l}0.372 * * * \\
(0.0653)\end{array}$ & & \\
\hline n_destroyed_2 & & & & & & & & & $\begin{array}{c}0.240 * * * \\
(0.0621)\end{array}$ \\
\hline n_rebels & & & & & & & $\begin{array}{l}-0.430 \\
(0.410)\end{array}$ & & $\begin{array}{l}-0.852^{*} \\
(0.435)\end{array}$ \\
\hline $\begin{array}{l}\text { Controls for altitude } \\
\text { and distances }\end{array}$ & no & no & no & no & no & no & yes & no & yes \\
\hline $\begin{array}{l}\text { Controls for latitude } \\
\text { and longitude }\end{array}$ & yes & yes & yes & yes & yes & yes & yes & yes & yes \\
\hline Observations & 530 & 530 & 530 & 530 & 530 & 530 & 530 & 530 & 530 \\
\hline Pseudo $\mathrm{R}^{2}$ & 0.308 & 0.355 & 0.384 & 0.326 & 0.344 & 0.372 & 0.523 & 0.497 & 0.624 \\
\hline
\end{tabular}


Note: The estimator is binomial probit in all specifications. A constant with unreported coefficients has been included in each specification. Robust standard errors in parentheses. Clustered standard errors are used in column (2)-(3) on the basis of the six units of variation in rainfall. $* * * \mathrm{p}<0.01, * * \mathrm{p}<0.05, * \mathrm{p}<0.1$. Controls for altitude and distance to major towns includes d_elgen, d_elfash, and d_nyala. 
Table 4: Selected changes in probabilities for destroyed

\begin{tabular}{lcccc}
\hline VARIABLES & marginal effect & mean & -+st dev/2 & min->max \\
\hline rebeltribes & $0.907^{* * *}$ & 0.615 & 0.394 & 0.710 \\
d_wadi & -0.006 & 6.38 & -0.047 & -0.219 \\
rainfall & $0.001^{* *}$ & 704.9 & 0.097 & 0.308 \\
vegetation & $-10.544^{* * *}$ & 0.174 & -0.153 & -0.494 \\
temperature & $0.155^{*}$ & 25.34 & 0.080 & 0.521 \\
soilquality & $0.146^{* * *}$ & 3.575 & 0.138 & 0.368 \\
d_admin & $0.006^{* *}$ & 26.8 & 0.099 & 0.442 \\
\hline
\end{tabular}

Note: Calculation is based upon specification 3 in table 3 with all other variables held at their mean. $* * * p<0.01, * *$ $\mathrm{p}<0.05, * \mathrm{p}<0.1$. The column with the "marginal effect" shows the partial derivative of the listed variables at their means. The column "min->max" displays the changes in predicted probability of destroyed when the listed variables increases from their minimum value to their maximum value. "-+st dev/2" shows the change in predicted probability of destroyed when the listed variables increases from $1 / 2$ standard deviation below their mean to $1 / 2$ standard deviation above the mean. 
Table 5: Number of households displaced

\begin{tabular}{|c|c|c|c|c|c|c|c|c|}
\hline VARIABLES & $\begin{array}{c}(1) \\
\text { log } \\
\text { peoplefled } \\
\text { (Full sample) }\end{array}$ & $\begin{array}{c}(2) \\
\text { log } \\
\text { peoplefled } \\
\text { (Full sample) }\end{array}$ & $\begin{array}{c}(3) \\
\text { log } \\
\text { peoplefled } \\
\text { (Full sample) }\end{array}$ & $\begin{array}{c}\text { (4) } \\
\text { log } \\
\text { peoplefled } \\
\text { (Full sample) }\end{array}$ & $\begin{array}{c}(5) \\
\text { log } \\
\text { peoplefled } \\
\text { (Full sample) }\end{array}$ & $\begin{array}{c}(6) \\
\text { log } \\
\text { peoplefled } \\
\text { (Full sample) }\end{array}$ & $\begin{array}{c}(7) \\
\log \\
\text { peoplefled } \\
(\text { peoplefled }>0 \text { ) }\end{array}$ & $\begin{array}{c}(8) \\
\log \\
\text { peoplefled } \\
(\text { peoplefled }>0)\end{array}$ \\
\hline rebeltribes & $\begin{array}{c}2.661 * * * \\
(0.112)\end{array}$ & $\begin{array}{c}1.452 * * * \\
(0.176)\end{array}$ & $\begin{array}{c}1.473 * * * \\
(0.265)\end{array}$ & $\begin{array}{c}1.447 * * * \\
(0.177)\end{array}$ & $\begin{array}{c}1.447 * * * \\
(0.177)\end{array}$ & $\begin{array}{c}1.487 * * * \\
(0.179)\end{array}$ & $\begin{array}{c}0.6843 * * * \\
(0.122)\end{array}$ & $\begin{array}{c}0.553 * * * \\
(0.132)\end{array}$ \\
\hline arabs & & $\begin{array}{c}-1.904 * * * \\
(0.202)\end{array}$ & $\begin{array}{c}-1.887 * * * \\
(0.282)\end{array}$ & $\begin{array}{c}-1.948 * * * \\
(0.197)\end{array}$ & $\begin{array}{c}-1.939 * * * \\
(0.201)\end{array}$ & $\begin{array}{c}-1.892 * * * \\
(0.198)\end{array}$ & & $\begin{array}{c}-1.006^{* *} \\
(0.497)\end{array}$ \\
\hline d_wadi & $\begin{array}{c}-0.0268 * * * \\
(0.00660)\end{array}$ & $\begin{array}{l}-0.0134 * * \\
(0.00548)\end{array}$ & $\begin{array}{c}-0.00988^{* *} \\
(0.00363)\end{array}$ & & & $\begin{array}{l}-0.00731 \\
(0.00559)\end{array}$ & $\begin{array}{c}-0.006 \\
(0.0037)\end{array}$ & $\begin{array}{l}-0.004 \\
(0.004)\end{array}$ \\
\hline rainfall & & & $\begin{array}{c}0.00292 * * * \\
(0.000340)\end{array}$ & & & $\begin{array}{c}0.00322 * * * \\
(0.00114)\end{array}$ & & $\begin{array}{l}0.0017 * * \\
(0.0001)\end{array}$ \\
\hline vegetation & & & $\begin{array}{c}-14.14 * * * \\
(1.288)\end{array}$ & & & & & \\
\hline temperature & & & $\begin{array}{l}0.271 * * \\
(0.0729)\end{array}$ & & & & & \\
\hline soilquality & & & $\begin{array}{l}-0.120 * * \\
(0.0302)\end{array}$ & & & & & \\
\hline pcnatres & & & & $\begin{array}{c}0.0360 \\
(0.0270)\end{array}$ & $\begin{array}{c}0.0163 \\
(0.0786)\end{array}$ & & & \\
\hline rebel_natres & & & & & $\begin{array}{c}0.0254 \\
(0.0802)\end{array}$ & & & \\
\hline d_admin & $\begin{array}{c}0.00577 * * \\
(0.00271)\end{array}$ & $\begin{array}{c}0.00289 \\
(0.00238)\end{array}$ & $\begin{array}{c}0.00121 \\
(0.00104)\end{array}$ & $\begin{array}{c}0.00190 \\
(0.00240)\end{array}$ & $\begin{array}{c}0.00198 \\
(0.00238)\end{array}$ & $\begin{array}{l}-0.00297 \\
(0.00318)\end{array}$ & $\begin{array}{c}-0.002 \\
(0.002)\end{array}$ & $\begin{array}{l}-0.006 \\
(0.002)\end{array}$ \\
\hline log popsize & $\begin{array}{c}0.882 * * * \\
(0.0413)\end{array}$ & $\begin{array}{l}0.837 * * * \\
(0.0359)\end{array}$ & $\begin{array}{l}0.837 * * * \\
(0.0234)\end{array}$ & $\begin{array}{l}0.796 * * * \\
(0.0370)\end{array}$ & $\begin{array}{l}0.796 * * * \\
(0.0370)\end{array}$ & $\begin{array}{l}0.811 * * * \\
(0.0366)\end{array}$ & $\begin{array}{c}0.903 * * * \\
(0.027)\end{array}$ & $\begin{array}{c}0.919 * * * \\
(0.024)\end{array}$ \\
\hline $\log$ n_popsize & & & & $\begin{array}{l}0.0700 * * \\
(0.0291)\end{array}$ & $\begin{array}{l}0.0698 * * \\
(0.0291)\end{array}$ & $\begin{array}{c}0.0835 * * * \\
(0.0311)\end{array}$ & & $\begin{array}{c}0.017 \\
(0.016)\end{array}$ \\
\hline Constant & $\begin{array}{c}15.39 * * * \\
(3.070)\end{array}$ & $\begin{array}{c}2.429 \\
(2.530)\end{array}$ & $\begin{array}{l}-6.256^{*} \\
(2.564)\end{array}$ & $\begin{array}{l}-0.329 \\
(2.265)\end{array}$ & $\begin{array}{l}-0.0721 \\
(2.483)\end{array}$ & $\begin{array}{c}-145.6 * * * \\
(42.85)\end{array}$ & $\begin{array}{l}-0.695 \\
(2.077)\end{array}$ & $\begin{array}{c}-112.5 * * * \\
(29.37)\end{array}$ \\
\hline $\begin{array}{l}\text { Controls for altitude } \\
\text { and distances }\end{array}$ & no & no & no & no & no & yes & no & yes \\
\hline and longitude & yes & yes & yes & yes & yes & yes & yes & yes \\
\hline Observations & 530 & 530 & 530 & 530 & 530 & 530 & 400 & 400 \\
\hline R-squared & 0.783 & 0.849 & 0.852 & 0.849 & 0.849 & 0.857 & 0.830 & 0.849 \\
\hline
\end{tabular}


Note: The estimator is OLS. Robust standard errors in parentheses in all specifications except in column (3) where clustered standard errors are used on the basis of the six units of variation in rainfall. ${ }^{* * *} \mathrm{p}<0.01,{ }^{* *} \mathrm{p}<0.05,{ }^{*} \mathrm{p}<0.1$. Controls for altitude and distance to major towns includes $d$ elgen, $d$ elfash, and

d_nyala. 
Appendix A: Example of measurement of $d \_$wadi and some other variables

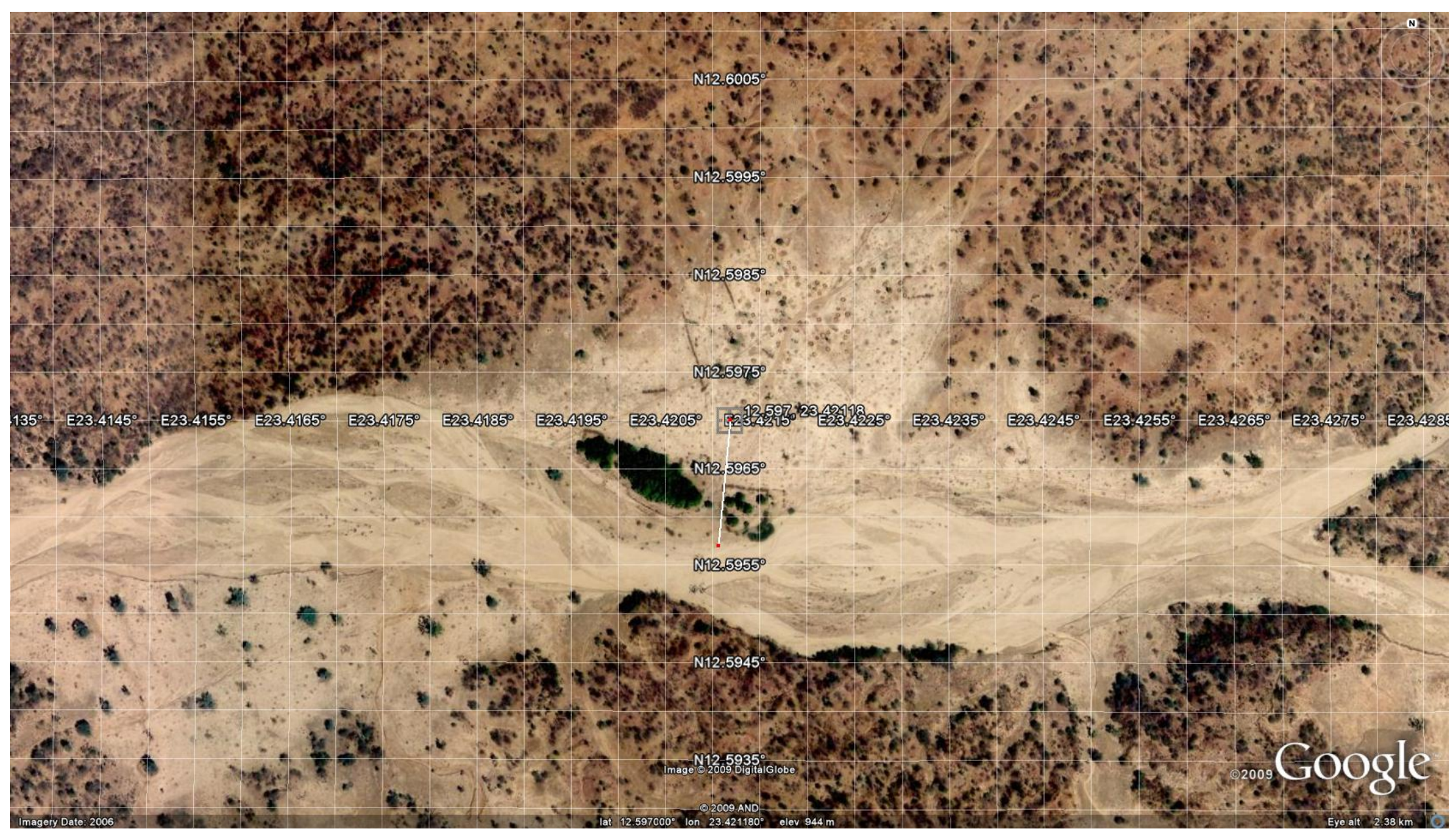

Note: The figure shows the destroyed village of Sede in Garsila administrative unit. The small dark circles in the middle of the picture are destroyed and burned huts. Distance to wadi in this case is only 150 meters $\left(d_{-}\right.$wadi $\left.=0.15\right)$. In constructing the variable, we always use the exact coordinates for village location provided by our main source and then measure the nearest distance to the bank of the nearest major wadi (with a substantial portion more than 100 meters wide). Although the width of wadis typically varies locally, the wadi in the picture is approximately 140 meters wide immediately southeast of the village and thus qualifies as a major wadi. 
altitude above sea level is 944 meters at this location, the distance to the administrative center (Garsila) is large (d_admin=40.2). 240 households, all belonging to the Fur ethnic group (rebeltribes=1) lived here before the conflict and all fled (peoplefled=240; propfled=1). The two other villages in Sede's neighbourhood grid cell, which were both also 100 percent Fur before the conflict $(n$ rebels $=1)$, were also destroyed ( $n$ destroyed $=3$ ) and 530 households fled in total

(n_peoplefled $=530)$. At the latest visit by data collecting personnel on April 12, 2007, Sede was still abandoned. 
Appendix B: Number of destroyed or abandoned villages in 151 populated $10 \mathrm{~km}-\mathrm{by}-10 \mathrm{~km}$ grid cells

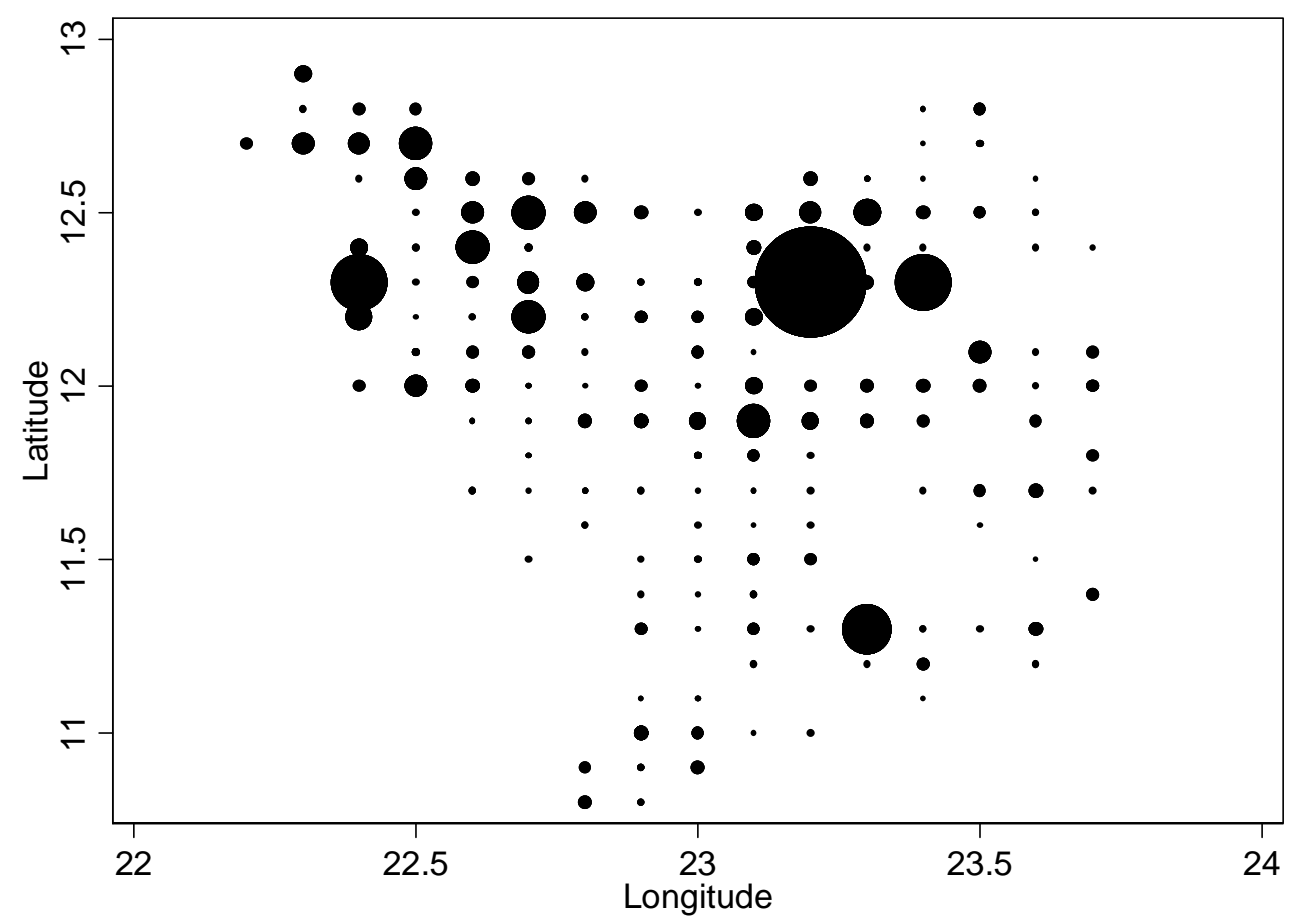

Note: The figure illustrates the construction of $15110 \mathrm{~km}$-by-10 km (or, more precisely, 0.1 latitude by 0.1 longitude degrees) grid cells with the size of each circle indicating the number of either destroyed or abandoned villages (destroyed_2) in the particular grid cell. The largest circle reflects 13 villages whereas the smallest circles reflect 0 destroyed villages. 
Appendix C: Auxiliary probit regressions using alternative resource variables

\begin{tabular}{|c|c|c|c|c|c|c|c|}
\hline VARIABLES & $\begin{array}{c}\text { (1) } \\
\text { destroyed }\end{array}$ & $\begin{array}{c}(2) \\
\text { destroyed }\end{array}$ & $\begin{array}{c}\text { (3) } \\
\text { destroyed }\end{array}$ & $\begin{array}{c}(4) \\
\text { destroyed }\end{array}$ & $\begin{array}{c}\text { (5) } \\
\text { destroyed }\end{array}$ & $\begin{array}{c}\text { (6) } \\
\text { destroyed }\end{array}$ & $\begin{array}{c}(7) \\
\text { destroyed }\end{array}$ \\
\hline rebeltribes & $\begin{array}{c}2.272^{* * * *} \\
(0.384)\end{array}$ & $\begin{array}{c}2.334 * * * \\
(0.389)\end{array}$ & $\begin{array}{c}2.334 * * * \\
(0.389)\end{array}$ & $\begin{array}{c}2.332 * * * \\
(0.347)\end{array}$ & $\begin{array}{c}2.304 * * * \\
(0.378)\end{array}$ & $\begin{array}{c}2.269 * * * \\
(0.377)\end{array}$ & $\begin{array}{c}2.329 * * * \\
(0.397)\end{array}$ \\
\hline d_wadi & $\begin{array}{c}-0.0106 \\
(0.0131)\end{array}$ & $\begin{array}{c}-0.0151 \\
(0.0122)\end{array}$ & $\begin{array}{l}-0.0151 \\
(0.0122)\end{array}$ & $\begin{array}{c}-0.0153 \\
(0.0121)\end{array}$ & $\begin{array}{l}-0.0149 \\
(0.0123)\end{array}$ & $\begin{array}{l}-0.0166 \\
(0.0115)\end{array}$ & \\
\hline rainfall & $\begin{array}{c}0.00324 * \\
(0.00166)\end{array}$ & $\begin{array}{l}0.00660^{*} \\
(0.00377)\end{array}$ & $\begin{array}{c}0.00410 * * \\
(0.00192)\end{array}$ & $\begin{array}{c}0.00384 * * \\
(0.00171)\end{array}$ & & & $\begin{array}{c}0.00437 * * * \\
(0.000934)\end{array}$ \\
\hline vegetation & $\begin{array}{c}-26.78^{* *} \\
(11.40)\end{array}$ & $\begin{array}{c}-32.95 * * \\
(14.20)\end{array}$ & $\begin{array}{c}-29.12 * * \\
(11.45)\end{array}$ & $\begin{array}{c}-25.09 * * \\
(10.26)\end{array}$ & $\begin{array}{c}-21.39 * * * \\
(7.503)\end{array}$ & $\begin{array}{c}-13.08 * * * \\
(3.731)\end{array}$ & $\begin{array}{c}-34.00^{* * *} \\
(9.140)\end{array}$ \\
\hline temperature & $\begin{array}{c}0.334 \\
(0.225)\end{array}$ & $\begin{array}{l}0.627^{*} \\
(0.343)\end{array}$ & $\begin{array}{l}0.594^{*} \\
(0.319)\end{array}$ & $\begin{array}{c}0.422 * * \\
(0.188)\end{array}$ & $\begin{array}{l}0.370^{*} \\
(0.205)\end{array}$ & $\begin{array}{l}0.524^{*} \\
(0.275)\end{array}$ & $\begin{array}{c}0.638^{* *} \\
(0.294)\end{array}$ \\
\hline soilquality & $\begin{array}{c}0.384 * * * \\
(0.112)\end{array}$ & $\begin{array}{c}0.593 * * * \\
(0.0989)\end{array}$ & $\begin{array}{c}0.237 \\
(0.184)\end{array}$ & $\begin{array}{c}0.366^{* * *} \\
(0.106)\end{array}$ & $\begin{array}{c}0.246 \\
(0.162)\end{array}$ & $\begin{array}{c}0.443 * * * \\
(0.0903)\end{array}$ & $\begin{array}{l}0.0664 \\
(0.237)\end{array}$ \\
\hline cropsuit & $\begin{array}{c}0.357 \\
(0.281)\end{array}$ & & & & & & \\
\hline livestock_crop & & $\begin{array}{c}-0.0394 \\
(0.0299)\end{array}$ & & & & & \\
\hline cattle & & & $\begin{array}{l}-0.178 \\
(0.135)\end{array}$ & & & & \\
\hline grazingrisk & & & & $\begin{array}{c}0.340 \\
(0.220)\end{array}$ & & & \\
\hline soilmoisture & & & & & $\begin{array}{c}0.0961 * * \\
(0.0452)\end{array}$ & & \\
\hline pet_avg & & & & & & $\begin{array}{c}-0.00367 * * \\
(0.00157)\end{array}$ & \\
\hline water_points & & & & & & & $\begin{array}{c}0.567 \\
(0.412)\end{array}$ \\
\hline $\begin{array}{l}\text { Controls for } \\
\text { d_admin, popsize, } \\
\text { latitude, and } \\
\text { longitude }\end{array}$ & yes & yes & yes & yes & yes & yes & yes \\
\hline Observations & 530 & 530 & 530 & 530 & 530 & 530 & 530 \\
\hline Pseudo $\mathrm{R}^{2}$ & 0.390 & 0.385 & 0.385 & 0.388 & 0.385 & 0.383 & 0.382 \\
\hline
\end{tabular}

Note: The estimator is binomial probit in all specifications. A constant with unreported coefficients has been included in each specification. Robust standard errors in parentheses. Clustered standard errors are used in all columns on the basis of the six units of variation in rainfall. $* * * \mathrm{p}<0.01, * * \mathrm{p}<0.05, * \mathrm{p}<0.1$. Controls for altitude and distance to major towns includes $d \_$elgen, $d \_$elfash, and $d \_n y a l a$. 
Additional resource variables

\begin{tabular}{|c|c|c|c|c|c|c|}
\hline Variable & Description & Obs & Mean & $\begin{array}{l}\text { Std. } \\
\text { dev. }\end{array}$ & Min & Max \\
\hline cropsuit & $\begin{array}{l}\text { Binary dummy for area where more than } 50 \\
\text { percent of the land is considered marginally or } \\
\text { very suitable for cultivation of paddy rice or } \\
\text { upland crops }\end{array}$ & 530 & 0.3 & 0.4587 & 0 & 1 \\
\hline livestock_crop & $\begin{array}{l}\text { Average livestock to crop ratio in percent in } \\
\text { village's climate zone }\end{array}$ & 530 & 65.44 & 9.78 & 40 & 70 \\
\hline cattle & $\begin{array}{l}\text { Average share of cattle in the herd } \\
\text { composition in percent in village's climate } \\
\text { zone }\end{array}$ & 530 & 50.10 & 0.63 & 46 & 51 \\
\hline grazingrisk & $\begin{array}{l}\text { Binary dummy for areas with exceptional risk } \\
\text { of overgrazing }\end{array}$ & 530 & & & 0 & 1 \\
\hline soilmoisture & $\begin{array}{l}\text { Average readily available soil moisture in } \\
\text { mms in village's climate zone }\end{array}$ & 530 & 87.73 & 2.97 & 79 & 89 \\
\hline pet_avg & $\begin{array}{l}\text { Average annual potential evapotranspiration } \\
\text { in mms in village's climate zone }\end{array}$ & 530 & 2071.4 & 29.74 & 1996 & 2188 \\
\hline water_points & $\begin{array}{l}\text { Typical access to water points in village's } \\
\text { climate zone; } 1=\text { poor, } 2=\text { fair, } 3=\text { good }\end{array}$ & 530 & 1.85 & 0.397 & 1 & 3 \\
\hline
\end{tabular}

Source: FAO (1998) 